\title{
Nutritional compositions and their retention rates of carrots by different cooking methods
}

\author{
Kunjong Lee ${ }^{1}$, Heajung Chung ${ }^{2 *}$ \\ ${ }^{1}$ Department of Food Science and Nutrition, Soongeui Women's College, Seoul 04628, Korea \\ ${ }^{2}$ Department of Korean Cuisine, Jeonju University, Jeonju 55069, Korea \\ 다양한 조리법에 따른 당근의 영양성분 함량과 영양소 잔존율 \\ 이근종 ${ }^{1} \cdot$ 정혜정 ${ }^{2 *}$ \\ ${ }^{1}$ 숭의여자대학교 식품영양과, ${ }^{2}$ 전주대학교 한식조리학과
}

\begin{abstract}
Proximate components and mineral contents of Daucus carota L. were investigated following cooking using 5 different methods (i.e., boiling, pan-roasting, stir-frying, deep-fat frying, and steaming), and their retention rates were also evaluated. Weight loss was evaluated in all cooked carrot samples, and significant difference in $(p<0.05)$ proximate components and mineral contents were found upon variation in the cooking method. The highest protein, fat, and ash contents were detected in deep-fried carrots, while a high content was found in raw, boiled, and steamed carrots. In retention rates of carrot by cooking method, frying sifnificantly lowered $40.89 \%$. Mineral $(\mathrm{Na}, \mathrm{Fe}, \mathrm{Cu})$ retention rates were significantly lowered by boiling and steaming, resulting in rates of $70 \%$. Carrots were cooked by using different methods and the retention rates of $\beta$-carotene and vitamin $E$ according to cooking methods of carrots were investigated., In amino acid retention rates, deep-frying was lowest examined (Arg: 61.64\%, Cys: 93.97\%). Therefore, these data can be used as a basis for the processing of carrots.
\end{abstract}

Key words : carrots, cooking methods, retention factor

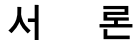

현대사회의 서구화된 식습관으로 아동과 성인은 다양 한 성인병을 않고 있으며, 이러한 성인병을 극복하고자 황색 당근뿐만 아니라, 안토시아닌 계통의 자색 당근과 같이 항산화 물질에 관한 연구가 활발하게 진행되고 있다. 이처럼 항산화 능이 뛰어난 색채 식품에 관한 관심이 점점 높아지고 있는 추세이다(Choi, 2011; Kang, 2016). 당근은 미나리과에 속하는 근채류로 학명이 Daucus carota L.인 대표적인 뿌리채소이다. 당근의 영양성분은 수분이 약 $90 \%$ 를 차지하며 단백질이 $1 \%$, 당질이 7.8 을 차지하며 회
분 $0.6-1.1 \mathrm{~g}, \mathrm{Ca} 38 \mathrm{mg}, \mathrm{P} 37 \mathrm{mg}, \mathrm{Na} 26 \mathrm{mg}$, 칼륨 400 $\mathrm{mg}$ 을 차지하며, 비타민이 1,257 - 7,300 $\mu \mathrm{g}$ R.E로 carotene 이 주성분이다(NRRDI, 2019). 활성산소를 제거하는 역할 을 하며, 식품에 포함된 $\beta$-carotene은 비타민 $\mathrm{A}$ 의 전구체로 써 카로티노이드 색소를 많이 함유하고 있다. 당근에는 지질과산화반응의 연쇄반응을 차단하는 항산화 물질을 많이 함유하고 있어서 몸속에서 만들어지는 활성산소를 제거하고 노화를 억제해주는 대표적인 식품이라고 보고 하였다(Krinsky, 1989a). 또한, 당근의 항비만, 항균, 항암작 용 등이 보고되었다(Krinsky, 1988b; Han, 2015). 성인병 예방을 위한 효능 등 다양한 생체조절기능이 보고됨에

*Corresponding author. E-mail : angiechung@hanmail.net, Phone : +82-63-220-2098, Fax : +82-63-220-2736

Received 06 February 2020; Revised 02 April 2020; Accepted 16 April 2020.

Copyright (c) The Korean Society of Food Preservation.

This is an Open Access article distributed under the terms of the Creative Commons Attribution Non-Commercial License (http://creativecommons.org/licenses/by-nc/4.0) which permits unrestricted non-commercial use, distribution, and reproduction in any medium, provided the original work is properly cited. 
따라 기능성 식품으로 관심이 증가하고 있으며, 당근의 여러 가지 조리법과 제품개발 연구가 활발히 이루어지고 있다(Krinsky, 1989a). 최근에는 고추와 파프리카, 오이에 대한 조리가공방법을 달리하여 잔존 영양소 함량을 측정 하여 비교하고자 하는 연구가 진행되었다 $(\mathrm{Kim}, 2017$; Kim 과 Chung, 2017). 무와 당근에 대해서 소금 농도를 달리하 여 데치기와 고열로 찌기를 하였을 때 $\mathrm{pH}$, 미생물, 물성 및 비타민 $\mathrm{C}$ 에 대해 분석을 하였으며, 삶거나 찌는 조리조 작에서 조직감의 차이가 있다고 보고하였고, 비타민 $\mathrm{C}$ 는 조리방법이나 시간에 상관없이 원재료보다 $50 \%$ 이상 낮 아졌다고 보고되었다(Ahn, 1999; Kim, 2003).

Paek 등(2019)에 따르면 국내와 일본에서는 우엉, 더덕, 도라지와 연근과 같은 뿌리채소를 넣어 된장을 담그면 아미노태질소의 함량은 감소하지만, 우엉 된장의 경우 대 조구보다 구수한 맛이 높은 것으로 나타났는데, 최근에 국내뿐만 아니라, 일본 등에서는 당근 등 뿌리채소류를 된장국 재료로 첨가한다고 보고하였다. 된장과 같은 물에 넣는 요리에서 당근을 넣는다면 국물에 수용성 성분의 영양소뿐만 아니라, $1 \%$ 나 되는 아미노산 성분이 용출되어 나와서 함께 섭취할 수 있으므로 바람직한 조리법인지 확인할 필요성이 있다. 지금까지 알려진 당근의 조리법은 주로 지용성 비타민이 많으므로 주로 볶기나 튀기기와 같은 기름을 이용한 조리법은 지용성 비타민과 지방산의 섭취 급원으로 적당하다. 그러나, 지방산의 산화로 인한 산가 증가 등이 문제가 되고 있으며, 실제 지방산의 변화에 관한 연구가 미비한 실정이다. 실제 프로비타민인 카로티 노이드는 물속에 끓이거나 마이크로오븐에 가열하면 일 부 파괴되는 것으로 알려져 있으며, 산화된 카로티노이드 의 파괴가 일어나서 cis-isomers가 형성되고, 가열시간이 증가하면 더 많은 파괴를 일으킨다고 보고되었다 $(\mathrm{Kim}$ 등, 2003). 조리 중 변성이 일어나게 되므로 가능한 전통 한식 조리법과 비교한 연구 자료가 부족한 실정이므로 추가적 인 연구가 더 필요하다.

지금까지 당근 자체는 주재료가 아닌 음식의 부재료로 써 주로 활용되는데, 국내에서는 당근주스, 소스, 피클, 절편, 당근을 첨가한 녹두전분 겔 및 정과 등이 조리법이 보고되었다(Lee, 2000; Hong, 2009; Kim, 2009; Cha, 2011; $\mathrm{Oh}, 2012$; Kim, 2014a). 그러나, 당근의 여러 가지 조리방법 에 관한 잔존율과 영양성분 데이터는 적은 편이다. 최근에 닭고기, 돼지고기, 쇠고기 등의 품종, 부위 등에 대한 일반 성분, 지방산, 총 아미노산량 및 무기질 등에 관한 연구가 진행되었다. 취청오이, 다다기, 노각 등(Kim 등, 2017)과 버섯류(Park 등, 2017)의 삶기, 굽기, 튀기기, 로스팅 및 전자레인지 등을 활용하여 무기질의 영양소 함량 분석 (Kim과 Chung, 2017)과 당근의 다양한 전 처리 및 조리방 법에 따른 이화학적 특성 등을 보고하였다.
잔존량계수에 대한 연구는 미국에서는 1970년대부터 농무성(USDA)에서 활발한 연구가 진행됐고(USDA, 2017), 최근에 식품의약품안전처와 국내 여러 대학과 분석기관 에서 식품을 조리한 후 영양소의 조리가공계수와 잔존량 계수에 관한 연구가 활발하게 진행되고 있다(Kim, 2017a; Lee, 2014; Kim, 2017b; Kim과 Chung, 2017; Park, 2017). 한우는 부위와 조리방법에 따라 잔존율의 함량 차이가 매우 크다고 보고되었다(Kim, 2010; Lee, 2014). 삼겹살과 가금류의 조리방법과 부위에 따른 물리 - 화학적 특성 변 화의 영양소 함량 및 아미노산의 함량 차이가 난다고 보고 하였다(Yang 등, 2009; Jeon 등, 2014). 반면에 당근의 조리 법에 대한 품질변화에 관한 보고는 매우 미미한 실정이다 (Kim, 2012; Kim, 2014a).

본 연구를 통하여 당근을 각종 전통 조리법에 따라 제조 한 후 무기질, 카로티노이드, 비타민 $\mathrm{E}$, 아미노산, 당류 등 영양성분 함량을 조리가공계수와 잔존량 및 영양성분 함량 을 구할 필요성이 있다. 본 연구의 목적은 단백질과 필수아 미노산 및 기타 아미노산의 함량과 조성을 조사하여 다양 한 조리법에 따른 잔존율을 구하여 국민 영양 정책 수립을 위한 기초 데이터로 제공될 수 있을 것으로 사료된다.

\section{재료 및 방법}

\section{시료 전처리}

본 연구에 사용된 채소류인 당근을 전북 전주시 농산물 시장에서 구매하여 시료로 사용하였다. 조리조건에 따른 영양소 함량과 잔존율 계수를 분석하여 함량 변화를 다음 과 같은 조리조건으로 분석하였다. 실험에 사용된 모든 재료는 증류수를 사용하여 씻어 전처리를 하였다.

\section{시약}

무기질 분석은 $\mathrm{HNO}_{3}: \mathrm{H}_{2} \mathrm{O}_{2}-9: 1$ 분석에 사용된 표준시약 은 Sigma-Aldrich Co.(St. Louis, MO, USA)급으로 분석하였 다. 표준시약은 Sigma-Aldrich Co.의 제품을 사용하였고, 분석 시 사용된 $\mathrm{KOH}$ (sodium hydroxide, Siheung, Korea), $\mathrm{Na}_{2} \mathrm{SO}_{4}$ )(sodium sulfate anhydrous, Tokyo, Japan), $\mathrm{CHCl}_{3}$ (chloroform, J. T. Baker, Philipsburg, NJ, USA), $\mathrm{C}_{6} \mathrm{H}_{14}(\mathrm{n}$ hexane, J. T. Baker, Philipsburg)의 제품을 사용하였다. 아미 노산 분석법에 사용된 시약은 증류수, $6 \mathrm{~N}$ 염산용액, 질소가 스(99.9\%), 아미노산 표준원 액으로 Sigma AAS18-10 ML Sigma-Aldrich Co.에서 구입한 혼합용액[(aspartic acid(ASP), aserine(Ser), glutamic acid(Glu), glycine(Gly), histidine(His), threonine(Ther), arginine(Arg), alanine(Ala), proline(Pro), tyrosine(Try), valine(Val), methionine(Met), lysine(Lys), isoleucine(Ile), leucine(Leu), phenyalanine(Phe)]을 함유하 는 mixed standard를 사용하였고, 아미노산 표준용액은 위 
표준원 액을 각각 $0.01,0.025,0.05,0.100,0.250 \mu \mathrm{M} / \mathrm{mL}$ 의 농도가 되도록 증류수로 희석하여 사용하였다. Pyrogallol ethanol, 질소가스, $\mathrm{NaCl}$, hexane, ethyl acetate $=85: 15, \mathrm{v} / \mathrm{v}$, $0.01 \%$ butylhydroxy toluene, $\mathrm{BHT}, \mathrm{KOH}, \mathrm{CHCl}_{3}, \mathrm{O}=6: 1: 3$ 과 $\mathrm{MeOH}: \mathrm{BuOH}: \mathrm{H}_{2} \mathrm{O}=89.5: 10: 0.5$, 토코페롤, n-hexane, protease, $\alpha$-amylase, folate vonjugase(Pel-Freeze Biologicals, Rogers, AR, USA), Lactobacillus casei spp. rhamnosus(ATCC 7469) 을 사용하였고, Sigma-Aldrich 사에서 구매하였다.

\section{조리 방법}

실험에 사용된 모든 재료는 증류수를 사용하여 씻어 전처리를 하였다. 모든 시료는 가로 $3 \mathrm{~cm} \times 3 \mathrm{~cm}$ 크기로 절단한 후 균질화를 하였다. 삶기(boiling)는 인덕션의 $2,400 \mathrm{~W}$ 로 하여 증류수를 끓인 후 출력을 $1,400 \mathrm{~W}$ 로 낮춘 후 재료를 넣고 3 분간 삶았다. 굽기(pan-roasting)는 인덕션 (DIH-261DC, Daeyung, Seoul, Korea)을 1,800 W 출력으로 4분간 구웠다. 볶기는 1회 조리 시 식용유를 $15 \mathrm{~mL}$ 를 첨가 하여 팬에 $1,800 \mathrm{~W}$ 출력으로 4 분 30 초간 조리한 다음 종이 행주 2겹으로 1회 닦아내서 기름기를 제거하였다. 튀기기 (deep fat-frying)는 전기튀김기(DK-201, Delki, Goyang, Korea)를 $170^{\circ} \mathrm{C}$ 로 예열한 후 2 분 30 초 동안 조리하고, 키친 타올 3겹으로 3번 문질러서 기름기를 제거한 후 시료로 사용하였다. 볶기와 튀기기에 사용한 기름은 콩기름(pure refined soybean oil, Sajo, Seoul, Korea)을 사용하였다. 찌기 (steaming)는 인덕션을 $2,400 \mathrm{~W}$ 출력으로 하여 증류수를 가열한 뒤, $1,400 \mathrm{~W}$ 로 낮춘 후 3 분간 조리하고 재료를 뒤집은 다음 3 분간 쪘다. 모든 시료는 조리 직후 $-70^{\circ} \mathrm{C}$ deep freezer에서 냉동 보관하면서 균질기(HGBSS, Waring, Torrington, CT, USA)로 균질화한 후 다음 분석 시료로 사용하였다.

\section{성분분석기관}

본 연구의 성분분석은 기업체, 대학교, 연구소 등 영양성 분분석 전문기관에서 각 시료의 식품영양성분 국가관리 망(National Laboratory System, NLS)을 구축하여 분석품질 을 검증한 기관에서 분석하였다.

\section{일반성분 분석}

시료의 수분, 조단백질, 조지방, 조회분 등 일반성분분 석은 $\mathrm{AOAC}$ 의 방법에 따라서 분석하였다(AOAC, 1996).

\section{무기질 분석}

당근 중 무기질 분석은 식품공전법(KFIA, 2012)에 따라 분석하였다. 시료 $0.5 \mathrm{~g}$ 에 혼합액 $\left(\mathrm{HNO}_{3}: \mathrm{H}_{2} \mathrm{O}_{2}-9: 1\right)$ 으로 전 처리하였으며, microwave digestion system(Qwave 1000, Mississauga, Canada)에 넣고 30 분간 산 분해를 실시하였
다. 산 분해 후 시료 용액을 와트만 여과지(Whatman No. 41, Whatman International Ltd., Buckinhhamshire, UK)로 여과하여 사용하였다. $\mathrm{Na}, \mathrm{Ca}, \mathrm{K}, \mathrm{Mg}, \mathrm{P}, \mathrm{Fe}, \mathrm{Cu}, \mathrm{Zn}, \mathrm{Mn}$ 은 ICP-OES(AACTIVA, Horiba Jobin Yvon canal, France)로 Se는 ICP-MS(ICP-Mass, Perkin Elmer Co., Shelton, CT, USA)로 분석하였다. 무기질 별 분석조건은 Table 1, Table 2에 나타내었다.

\section{아미노산 분석}

Jang 등(2016)의 단백질분석법으로 분석하였다. 식품 중 의 단백질을 강산으로 가수분해하여 생성하는 아미노산 을 ion-exchange 컬럼을 통해 분리하고, ninhydrin post column 유도체화(Ruhemann's purple)를 형성 및 발색시켜 visible detector로 분석하는 방법이다. 아미노산자동분석 기는 Hitachi AAA 1-8900(Hitachi, Tokyo, Japan)로 분석하 였으며, 컬럼은 Hitachi 이온교환수지(ion exchange resin, $4.6 \times 60 \mathrm{~mm}$ )로 충진시킨 이온교환칼럼(ion exchange column) 과 이동상은 $\mathrm{pH} 1.0, \mathrm{pH} 2.0, \mathrm{pH} 3.0, \mathrm{pH} 4.0$, D.W., Re-generation solution, ninhydrin, 완충용액(buffer solution) 은 닌히드린(ninhydrin)유도화합물(compound)을 사용하 였다. 분석 조건은 $5 \%$ ethanol, 9 channel의 조건으로 컬럼 오븐 온도 및 post-column reactor 온도는 column ove 온도룰 20 에서 $85^{\circ} \mathrm{C}$ (increase $1^{\circ} \mathrm{C} /$ step), reaction unit: 50 에서 $140^{\circ} \mathrm{C}$ (increase $1^{\circ} \mathrm{C} / \mathrm{step}$ )로 분석하였고, 검출기는 가시광선영인 visible detecto에서 파장 $570 \mathrm{~nm}$ 에서 분석하였고 예외적으 로 proline만 $440 \mathrm{~nm}$ 에서 분석하였다. 시험용액 $20 \mu \mathrm{L}$ 를 아미노산자동분석기 내 주입하여 시험용액 중 아미노산 의 피크면적 또는 높이를 이용하여 아미노산 함량을 구한 다. 식품공전의 아미노산 계산식에 따라 시료 중의 아미노 산 함량을 계산하였다.

Table 1. Mineral (Na, Ca, K, P, Fe, Mg, Fe, Mg, Mn Cu, Zn) analitical conditions for carrot by ICP-OES

\begin{tabular}{cc}
\hline Description & $\begin{array}{c}\mathrm{Na}, \mathrm{Ca}, \mathrm{K}, \mathrm{P}, \mathrm{Fe}, \mathrm{Mg}, \mathrm{Mn}, \\
\mathrm{Cu}, \mathrm{Zn}\end{array}$ \\
\hline Nebulizer gas flow (L/min) & 0.8 \\
Plasma gas flow (L/min) & 15 \\
Auxiliary gas flow (L/min) & 0.2 \\
RF power (watts) & 1,300 \\
Viewing distance & 15 \\
Plasma view type & Radical axial \\
Spray chamber type & Scott type \\
Nebulizer & Gem tip cross-flow \\
nebullizer
\end{tabular}


Table 2. Se analysis condition of carrot by ICP-MS

\begin{tabular}{cc}
\hline Instrument & Condition \\
\hline Selected isotopes (M/Z) & $\mathrm{Se}^{82}$ \\
Measurement mode & Standard mode \\
Spray chamber & Cyclonic \\
Nebulizer & Mein hard \\
Sample uptake rate & $1 \mathrm{~mL} / \mathrm{min}$ \\
RF power & $1,500 \mathrm{~W}$ \\
Plasma gas flow (L/min) & 20 \\
Nebulizer gas flow (L/min) & 0.93 \\
Auxiliary gas flow (L/min) & 1.2 \\
Dwell time (ms) & 50 \\
Sweep per reading & 20 \\
Replicates & 3 \\
Delay time (s) & 50 \\
Wash time (s) & 45 \\
\hline
\end{tabular}

\section{비타민류 분석}

\section{베타카로틴 ( $\beta$-carotene)}

베타카로틴( $\beta$-carotene)의 분석은 Thomas 등(2001)의 방 법에 따라 알칼리 비누화법으로 추출한 후 $\mathrm{HPLC}$ 를 분석 하였다. 균질화된 시료를 추출관에 취하고 $6 \%$ pyrogallol ethanol 용액을 첨가한 후 10 분 동안 초음파처리(Sonicator, Cole-Parmer, Vernon Hills, IL, USA)하였다. 시료추출관에 $60 \% \mathrm{KOH}$ 용액 $8 \mathrm{~mL}$ 를 추출관에 가하고 잘 혼합한 후 추출관의 상부 공기를 질소로 치환시켰다. 치환된 추출관 을 $75^{\circ} \mathrm{C}, 100 \mathrm{rpm}$ 으로 조절된 shaking water bath(HB205SW, Hanbaek Sciencetific Co., Bucheon, Korea)에서 1시 간 동안 검화를 한 후 찬물에서 냉각하고, $2 \% \mathrm{NaCl}$ 용액 $20 \mathrm{~mL}$ 를 가하여 반응을 종결하였다. 검화액 추출용매 (hexane:ethylacetate $=85: 15, \mathrm{v} / \mathrm{v}, 0.01 \%$ butylhydroxy toluene, BHT) $15 \mathrm{~mL}$ 를 가한 다음 격렬하게 섞은 후 스탠드에 정치 시켜서 층을 분리하였다. 층 분리된 상등액을 $\mathrm{KOH}$ 가 채워 진 유리관에 통과시켜 추출액 중 수분제거를 한 후 50 $\mathrm{mL}$ 정용플라스크에 추출용매로 표선을 맞추어 정용하였 다. 이 과정을 3 회 반복하여 추출용액을 수집하였으며 추 출용매를 이용하여 $50 \mathrm{~mL}$ 까지 정용하였다. 추출물은 질소 농축한 후 잔류물을 $\mathrm{CHCl}_{3}$ 로 용해한 후 HPLC(Agilent, Santa Clara, CA, USA)를 이용하여 베타카로틴을 측정하였 다. 사용된 칼럼은 $\mathrm{Vydac} 201 \mathrm{TP} \mathrm{C}_{18}(4.6 \mathrm{~mm} \times 250 \mathrm{~mm}, 5$ $\mu \mathrm{m}, \mathrm{GRACE}, \mathrm{Santa}$ Clara, CA, USA)이며, 검출기는 PDA
detector(Agilent, $452 \mathrm{~nm}$ ), 이동상은 $\mathrm{MeOH}: \mathrm{BuOH}: \mathrm{H}_{2} \mathrm{O}=$ 6:1:3과 $\mathrm{MeOH}: \mathrm{BuOH}: \mathrm{H}_{2} \mathrm{O}=89.5: 10: 0.5$ 의 유기용매를 혼합 하여 사용하였고, 분석 시간은 65 분이었다.

\section{비타민 $\mathrm{E}$}

토코페롤은 Lee 등(1998)의 방법에 따라 알칼리 비누화 법으로 추출한 후 HPLC로 분석하였다. 추출법은 베타카 로틴과 같으며, 추출액을 질소 농축한 후 $\mathrm{n}$-hexane에 재용 해시켜서 $0.45 \mu \mathrm{m}$ membrane filter(Advantec, Tokyo, Japan) 를 사용하여 여과한 후 HPLC(LC-20AD, Shimadzu, Kyoto, Japan)로 측정하였다. 검출기(detector)는 형광검출기(링, Shimadzu, Ex $\lambda=290 \mathrm{~nm}, \mathrm{em} \lambda=330 \mathrm{~nm})$ 로 검출하였다. 칼럼 은 LiChrospher Diol 100(240×4 mm, $5 \mu \mathrm{m}$, Merk, Darmstadt, Germany)이며, 이동상으로 $0.9 \%$ isopropanol을 함유한 $\mathrm{n}$-hexane을 사용하였고, 시간은 총 35 분간 분석하였다.

\section{엽산}

엽산은 Chun 등(2006)의 방법에 따라 protease, $\alpha$-amylase, folate vonjugase(Pel-Freeze Biologicals, Rogers, AR, USA) 를 모두 처리한 trienzyme 방법으로 추출하여 이용하였다. 엽산의 분석법으로 Lactobacillus casei spp. rhamnosus (ATCC 7469)가 엽산의 농도에 따라 생육하는 정도를 측정 하는 미생물학적 방법(DeVries 등, 2005)을 사용하여 분석 하였다.

\section{조리가공계수(Processing factor) 산출}

시료의 중량을 조리 전후로 측정하여 중량의 증가 또는 감소를 $\mathrm{Kim}$ 등(2017)의 전보의 방법으로 계산하였다. 가공 계수는 공정과정 중에 생기는 중량의 증가 또는 감소의 양을 나타낸다.

Processing factor $(\%)=(\mathrm{Wc}) /(\mathrm{Wr}) \times 100$

$\mathrm{Wc}=$ weight of cooked food

$\mathrm{Wr}=$ weight of raw food

\section{잔존율(Retention ratio) 산출}

시료의 조리 전·후 시료의 중량을 이용하여 USDA의 기준에 따라 5 단계로 표시하는 영양소의 잔존율 계수는 Murphy 등(1975) retention factor 구하는 방법으로 계산하 였다.

True retention $(\%)=(\mathrm{Nc} \times \mathrm{Gc}) /(\mathrm{Nr} \times \mathrm{Gr}) \times 100$

$\mathrm{Nc}=$ nutrient content $/ \mathrm{g}$ of cooked food

$\mathrm{Gc}=\mathrm{g}$ of cooked food

$\mathrm{Nr}=$ nutrient content $/ \mathrm{g}$ of raw food 
$\mathrm{Gr}=\mathrm{g}$ of food before cooking

\section{통계처리}

반복 실험(3회 이상)한 결과를 SPSS 18.0 version(Statistics Package for the Social Science, Ver. 18.0 for Window, SPSS Inc., Chicago, IL, USA)으로 분석하였다. 시료 간 유의성 검정은 one-way ANOVA를 이용하여 분석하였으며, $\mathrm{p}<0.05$ 수준에서 Duncan's multiple range test를 실시하여 각 시료 간의 유의차 검정을 실시하였다.

\section{결과 및 결론}

\section{영양성분 함량}

수분, 탄수화물, 단백질, 총지방, 식이섬유, 회분

당근의 조리방법에 따른 실제 영양성분의 함량을 Table 3 에 나타내었다. 당근은 가열하면 조직이 수축하여 수분이 유출되며, 수분이 감소하는 결과가 나타났다. 수분 함량은 감소하는데, 이것은 $\mathrm{Kim}$ 등(2001)의 연구에 따르면 쇠고기 를 전자레인지(microwave)에 조리하였을 때 오븐에 굽거 나 볶은 것보다 가열감량이 많다고 보고하였다(Kim, 2001; Chae, 2003). 돈가스도 튀기거나 오븐에서 굽기가 오히려 수분함량의 차이가 적다고 보고하였다(Chae 등, 2003). 반 면에 당근은 자체 수분함량이 높아 굽기, 볶기, 튀기기 조리법에서 모두 수분함량이 유의적으로 감소하는 것으 로 나타났다. 삶거나 찌는 전통적인 조리법일수록 육류 중 지질을 제거하는 데 효과적인 조리법으로는 사료된다 (Kim 등, 2001). 당근은 특히, 팬에 굽기, 볶기, 튀기기를 하면 탄수화물, 단백질, 회분함량의 유의적인 차이가 나타 났다 $(\mathrm{p}<0.05)$. 단, 조리법에 따른 식이섬유는 굽기, 볶기,
튀기기 방법에서 증가하는 경향이었으나, 유의적인 차이 는 나타나지 않았다.

\section{무기질}

여러 가지 전통 조리법에 대한 무기질의 잔존 영양소 분석을 Table 4 에 나타내었다. 일반성분 함량은 전반적으 로 삶기를 하였을 때 다른 조리 방법에 비교하였을 때 유의적으로 낮게 나타났다. 무기질 성분의 팬에 볶을 때와 기름에 튀길 때 $\mathrm{Ca}, \mathrm{K}, \mathrm{Na}, \mathrm{P}, \mathrm{Mg}, \mathrm{Mn}, \mathrm{Se}, \mathrm{Zn}$ 함량이 유의적 으로 높게 나타났는데 $(\mathrm{p}<0.05)$, 이는 국내산 쇠고기 수육 의 영양소 잔존량에 관한 연구와 유사한 경향이었다(Kim, 2010; Lee, 2014).

칼슘 $(\mathrm{Ca})$ 의 함량은 생시료에서는 $23.7 \mathrm{mg} / 100 \mathrm{~g}$ 으로 나 타났는데, 기름에 볶거나 튀기면 $30.4 \mathrm{mg} / 100 \mathrm{~g}, 41.1$ $\mathrm{mg} / 100 \mathrm{~g}$ 으로 $1.3-1.7$ 배나 유의적으로 증가하는 것으로 나타났다 $(\mathrm{p}<0.001)$. 반면에 칼슘의 양은 삶거나, 찌기에서 생시료와 유사한 경향을 나타났다. 오븐에 굽거나(roasted) 전자레인지(microwaved)에 요리를 하면 시료 중 잔존율이 약 1.5 - 2 배가 증가한다는 결과와 유사하였다. 이러한 조 리법은 당근 중 수분이 많이 감소되는 조리법으로 조리를 하면 난용성 무기질인 칼슘의 잔존율이 상대적으로 증가 하는 것으로 사료된다. 당근 중 $\mathrm{K}$ 잔존량은 튀기기를 하면 $348.5 \mathrm{mg} / 100 \mathrm{~g}$ 으로 생시료의 $183.50 \mathrm{mg} / 100 \mathrm{~g}$ 에 비해 약 1.90 배 정도 증가하는 것으로 나타나, 튀기기가 가장 높게 증가하는 경향을 보였다. 이것은 Kim과 $\operatorname{Chung(2017)ㅇㅢ~}$ 보고에 따르면 오이를 종류별로 조리하였을 때 무기질의 함량이 증가하였다는 결과와 잘 일치하였다. 이는 조리과 정 중 수분감소로 인하여 상대적으로 고형분 함량이 증가 하는 것으로 보고 있다(Kim, 2014b). 굽기, 볶기, 찜을 하면 1.1 배, 1.3 배 및 1.3 배로 각각 증가하는 것으로 나타났다

Table 3. Comparison of carbohydrate, protein, fat, moisture and ash of carrot by different cooking methods

\begin{tabular}{cccccc}
\hline Cooking $^{1)}$ & $\begin{array}{c}\text { Moisture } \\
(\mathrm{g} / 100 \mathrm{~g})\end{array}$ & $\begin{array}{c}\text { Carbohydrate } \\
(\mathrm{g} / 100 \mathrm{~g})\end{array}$ & $\begin{array}{c}\text { Protein } \\
(\mathrm{g} / 100 \mathrm{~g})\end{array}$ & $\begin{array}{c}\text { Total fat } \\
(\mathrm{g} / 100 \mathrm{~g})\end{array}$ & $\begin{array}{c}\text { Ash } \\
(\mathrm{mg} / 100 \mathrm{~g})\end{array}$ \\
\hline RA1 & $91.9 \pm 0.3^{2) \mathrm{b} 3)}$ & $4.6 \pm 0.1^{\mathrm{bc}}$ & $0.8 \pm 0.0^{\mathrm{c}}$ & $0.2 \pm 0.3^{\mathrm{cd}}$ & $0.7 \pm 0.1$ \\
BO2 & $92.3 \pm 0.1^{\mathrm{a}}$ & $3.4 \pm 0.7^{\mathrm{c}}$ & $0.7 \pm 0.0^{\mathrm{d}}$ & $1.0 \pm 0.3^{\mathrm{cd}}$ & $0.5 \pm 0.1^{\mathrm{d}}$ \\
PR3 & $88.7 \pm 0.2^{\mathrm{d}}$ & $6.8 \pm 1.0^{\mathrm{a}}$ & $1.0 \pm 0.0^{\mathrm{b}}$ & $0.2 \pm 0.3^{\mathrm{cd}}$ & $0.9 \pm 0.0^{\mathrm{b}}$ \\
PF4 & $86.2 \pm 0.1^{\mathrm{e}}$ & $4.9 \pm 1.0^{\mathrm{b}}$ & $0.9 \pm 0.1^{\mathrm{b}}$ & $3.6 \pm 0.4^{\mathrm{b}}$ & $0.7 \pm 0.1^{\mathrm{c}}$ \\
DF5 & $81.1 \pm 0.2^{\mathrm{f}}$ & $6.7 \pm 0.6^{\mathrm{a}}$ & $1.1 \pm 0.0^{\mathrm{a}}$ & $5.3 \pm 0.9^{\mathrm{a}}$ & $1.0 \pm 0.1^{\mathrm{a}}$ \\
ST6 & $90.9 \pm 0.1^{\mathrm{c}}$ & $5.3 \pm 0.5^{\mathrm{b}}$ & $0.9 \pm 0.0^{\mathrm{c}}$ & $0.1 \pm 0.1^{\mathrm{d}}$ & $0.7 \pm 0.1^{\mathrm{c}}$ \\
\hline F-value & $2,141.8^{* * * 4)}$ & $9.7^{* * *}$ & $64.3^{* * *}$ & $76.3^{* * * *}$ & $33.9^{*}$ \\
\hline
\end{tabular}

${ }^{1)} \mathrm{RA1}$, control (raw material); BO2, boiling; PR3, pan-roasting; PF4, stir-frying; DF5, deep-frying; ST6, steaming.

${ }^{2)}$ Values are Mean $\pm \mathrm{SD}(\mathrm{n}=3)$.

3)a-f Means with different superscripts in a row are significantly different by the Duncan's multiple range test $\mathrm{p}<0.05$.

$\left.{ }^{4}\right)^{*}<0.05, \quad{ }^{* *} \mathrm{p}<0.01,{ }^{* * *} \mathrm{p}<0.001$. 
Table 4. Mineral contents of carrot by different cooking methods

(unit: $\mathrm{mg} / 100 \mathrm{~g}$ )

\begin{tabular}{cccccccccccc}
\hline Cooking $^{1)}$ & $\mathrm{Ca}$ & $\mathrm{K}$ & $\mathrm{Na}$ & $\mathrm{Fe}$ & $\mathrm{P}$ & $\mathrm{Mg}$ & $\mathrm{Mn}$ & $\mathrm{Se}$ & $\mathrm{Cu}$ & $\mathrm{Zn}$ \\
\hline RA1 & $23.7 \pm 2.3^{2 \mathrm{~d} 3)}$ & $183.5 \pm 28.0^{\mathrm{bc}}$ & $86.3 \pm 5.4^{\mathrm{b}}$ & $244.2 \pm 99.0$ & $26.4 \pm 2.1^{\mathrm{cd}}$ & $8.83 \pm 0.2^{\mathrm{e}}$ & $71.5 \pm 14.7^{\mathrm{c}}$ & $0.64 \pm 0.2$ & $32.4 \pm 7.3$ & $141.9 \pm 24.0^{\mathrm{cd}}$ \\
BO2 & $23.5 \pm 1.6^{\mathrm{d}}$ & $134.2 \pm 25.0^{\mathrm{c}}$ & $79.1 \pm 7.3^{\mathrm{b}}$ & $171.88 \pm 68.6$ & $23.04 \pm 1.2^{\mathrm{d}}$ & $7.8 \pm 0.3^{\mathrm{f}}$ & $71.2 \pm 13.5^{\mathrm{c}}$ & $0.7 \pm 0.2$ & $41.2 \pm 12.0$ & $128.6 \pm 19.7^{\mathrm{d}}$ \\
PR3 & $32.8 \pm 2.5^{\mathrm{b}}$ & $232.0 \pm 30.7^{\mathrm{b}}$ & $120.5 \pm 8.1^{\mathrm{a}}$ & $228.5 \pm 70.4$ & $33.02 \pm 2.0^{\mathrm{b}}$ & $14.4 \pm 0.7^{\mathrm{b}}$ & $112.6 \pm 11.4^{\mathrm{b}}$ & $0.8 \pm 0.2$ & $53.6 \pm 9.1^{\mathrm{a}}$ & $193.6 \pm 26.3^{\mathrm{ab}}$ \\
PF4 & $30.4 \pm 2.3^{\mathrm{bc}}$ & $233.8 \pm 39.6^{\mathrm{b}}$ & $79.9 \pm 3.2^{\mathrm{b}}$ & $234.9 \pm 100.6$ & $29.9 \pm 0.7^{\mathrm{bc}}$ & $11.5 \pm 0.3^{\mathrm{c}}$ & $120.1 \pm 0.7^{\mathrm{b}}$ & $0.7 \pm 0.1$ & $37.9 \pm 1.8$ & $180.1 \pm 24.6^{\mathrm{bc}}$ \\
DF5 & $41.1 \pm 2.2^{\mathrm{a}}$ & $348.5 \pm 14.1^{\mathrm{a}}$ & $125.7 \pm 5.7^{\mathrm{a}}$ & $284.4 \pm 100.6$ & $41.2 \pm 3.20^{\mathrm{a}}$ & $16.8 \pm 0.8^{\mathrm{a}}$ & $145.2 \pm 12.1^{\mathrm{a}}$ & $1.1 \pm 0.2$ & $47.8 \pm 7.3$ & $231.0 \pm 41.7^{\mathrm{a}}$ \\
ST6 & $26.9 \pm 2.0^{\mathrm{cd}}$ & $195.4 \pm 33.9^{\mathrm{b}}$ & $89.9 \pm 7.9^{\mathrm{b}}$ & $189.6 \pm 70.2$ & $29.9 \pm 3.1^{\mathrm{bc}}$ & $10.6 \pm 0.5^{\mathrm{d}} 107.4 \pm 11.7^{\mathrm{b}}$ & $0.7 \pm 0.2$ & $37.1 \pm 5.2$ & $151.7 \pm 14.0^{\mathrm{bcd}}$ \\
\hline F-value & $36.6^{* * * 4)}$ & $71.2^{* * *}$ & $171.8^{* * *}$ & 0.9 & $121.8^{* * *}$ & $157.4^{* * *}$ & $38.9^{* * *}$ & 1.2 & 0.9 & $3.9^{*}$ \\
\hline
\end{tabular}

${ }^{1)}$ RA1, control (raw material); BO2, boiling; PR3, pan-roasting; PF4, stir-frying; DF5, deep-frying; ST6, steaming.

${ }^{2)}$ Values are Mean \pm SD $(\mathrm{n}=3)$.

${ }^{3) a-f}$ Means with different superscripts in a row are significantly different by the Duncan's multiple range test $\mathrm{p}<0.05$.

${ }^{4} \mathrm{p}<0.05,{ }^{* *} \mathrm{p}<0.01,{ }^{* * *} \mathrm{p}<0.001$

$(\mathrm{p}<0.001)$. 이는 Ahn과 Song 등의 보고(Song, 1992; Ahn, 1999)에 따르면 볶기에서 칼슘 함량의 잔존량이 가장 높았 다는 보고와 유사하였다.

$\mathrm{Na}$ 의 함량은 $125.7 \mathrm{mg} / 100 \mathrm{~g}$ 으로 튀기기를 하면 가장 높게 나타났으며, 물에 삶기 $(79.1 \mathrm{mg} / 100 \mathrm{~g})$ 나 찌기 $(89.9$ $\mathrm{mg} / 100 \mathrm{~g}$ )를 하는 것이 $\mathrm{Na}$ 를 줄이는 데 도움을 주는 조리 법으로 나타났다 $(\mathrm{p}<0.001)$. 반면에 팬에 굽는 조리는 120.53 $\mathrm{mg} / 100 \mathrm{~g}$ 으로 나트륨 저감화에 영향을 미치지 못하였다. $\mathrm{Fe}$ 은 조리법에 따라 유의적인 차이가 없는 것으로 나타났 다. P는 튀김을 할 때 $41.2 \mathrm{mg} / 100 \mathrm{~g}$ 으로 유의적으로 높았 고, 팬에 굽기를 할 때 비교적 높은 양을 나타내었다. $\mathrm{P}$ 의 함량은 삶기를 할 경우 $23.0 \mathrm{mg} / 100 \mathrm{~g}$ 으로 가장 적게 나타 났다 $(\mathrm{p}<0.001)$. 인이 삶으면서 물 속에 용출되는 것으로 사료된다.

$\mathrm{Mg}$ 잔존량은 튀기기를 할 때 $16.8 \mathrm{mg} / 100 \mathrm{~g}$ 으로 가장 높았고, 굽기를 할 때 $14.4 \mathrm{mg} / 100 \mathrm{~g}$, 볶기 $11.5 \mathrm{mg} / 100$ $\mathrm{g}$ 순이었다. 이는 $\mathrm{Ahn}$ 등의 보고에서는 무기질이 대체로 감소한다는 보고와 유사하였는데, 특히 찌기는 $10.6 \mathrm{mg} /$ $100 \mathrm{~g}$, 삶기는 $7.8 \mathrm{mg} / 100 \mathrm{~g}$ 순서로 삶으면 $\mathrm{Mg}$ 손실이 가장 큰 것으로 나타났다. 이것은 당근을 물에 삶으면 마그 네슘의 구조 중 존재하던 클로로필 색소 성분 중 $\mathrm{Mg}$ 성분 이 수중으로 유출되었기 때문이라고 사료된다 $(\mathrm{p}<0.001)$. $\mathrm{Mn}$ 은 $145.2 \mathrm{mg} / 100 \mathrm{~g}$ 으로 가장 높게 나타났으며, 이는 생시료의 약 2 배나 증가한 것으로 기름에 볶으면 $\mathrm{Mn}$ 함량 이 1.5 배 정도 증가하게 나타났으며 굽기와 찌기에서도 증가하는 경향이었다 $(\mathrm{p}<0.001)$. 삶기는 생시료와 유사한 경향을 보였다. 항산화영양소인 $\mathrm{Se}$ 함량은 튀기기를 할 때 $1.1 \mathrm{mg} / 100 \mathrm{~g}$ 으로 가장 높은 경향을 보였고 굽기, 볶기, 삶기, 찌기 조리법의 유의차가 없었다. 식재료의 경우 식품 표면에서 흡유량에 따라 영양소 함량의 차이가 있는 것으
로 알려져 있다(Ziaiifar 등, 2008).

$\mathrm{Cu}$ 의 함량도 굽기, 튀기기 순이었으나 조리법에 따른 유의차가 없는 것으로 나타났다. $\mathrm{Zn}$ 은 $231.0 \mathrm{mg} / 100 \mathrm{~g}$ 으로 가장 높게 나타났고, 굽기 $(193.6 \mathrm{mg} / 100 \mathrm{~g})$, 볶기 $(180.1 \mathrm{mg} /$ $100 \mathrm{~g}$ ) 순이었고, 삶기를 하면 $128.6 \mathrm{mg} / 100 \mathrm{~g}$ 으로 오히려 감소하는 경향을 보였다. 따라서 삶으면 수용성 무기질 함량을 유의적으로 감소시켰다(p<0.001). 이는 Kim 등(2001) 의 연구에서 grilling이나 oven-roasting보다 panfrying이나 microwave에 조리하였을 때 가열감량이 증가하여 상대적 으로 무기질 함량이 높아진다는 보고와 유사한 결과이다.

\section{아미노산}

당근의 조리방법에 따른 실제 영양성분의 함량을 Table 5 에 나타내었다. 당근에 가장 높은 아미노산은 주로 글루 탐산 $(\mathrm{Glu})$ 으로 다른 아미노산에 비해 약 10 배 정도나 높았 다. 이는 갓김치의 아미노산 함량에서도 가장 높은 함량이 글루탐산이라는 보고와 일치하였고, 이것이 당근의 아미 노산 맛을 이루고 있는 것을 알 수 있었다(Jang 등, 2016). 그 밖에 모든 아미노산의 총 함량과 필수아미노산 등에 영향을 주는 것으로 나타났다 $(\mathrm{p}<0.05)$. 조리법에 따라 단 백질의 함량은 유의적인 차이가 있었고, 아미노산의 총량 도 일부 유의적인 차이를 나타내었다 $(\mathrm{p}<0.001)$. 아스파르트 산(Asp)(p<0.01), 세린(Ser)( $<<0.05)$, 글루탐산 $(\mathrm{Glu})(\mathrm{p}<0.001)$, 글리신(Gly)(p<0.01), 알라닌(Ala) $(\mathrm{p}<0.001)$, 페닐알라닌 $(\mathrm{Phe})(\mathrm{p}<0.01)$ 등에서 유의적인 차이를 보였다. 트레오닌 (Ther), 세린(Ser), 프롤린(Pro), 시스테인(Cys), 발린(Val), 메티오닌(Met), 이소루신(Ile), 루이신(Leu), 티로신(Tyr), 리신(Lys), 히스티딘(His), 아르기닌(Arg) 등의 아미노산 함량에는 조리법에 따른 유의적인 차이가 없었다. 이것은 팬에 볶거나 기름에 튀기는 고온에서 요리법은 단백질과 
Table 5. Amino acid contents of carrot by different cooking methods

(unit: $\mathrm{mg} / 100 \mathrm{~g}$ )

\begin{tabular}{|c|c|c|c|c|c|c|c|c|c|c|c|c|c|c|c|c|c|c|}
\hline Cooking & ASP & Thre & Ser & Glu & Pro & Gly & Ala & Cys & Val & Met & Ile & Leu & Tyr & Phe & Lys & His & Arg & $\begin{array}{c}\text { Total } \\
\text { amino } \\
\text { acid }\end{array}$ \\
\hline RA1 & $\begin{array}{c}104.7 \\
\pm 3.2^{2) b 3)}\end{array}$ & $\begin{array}{l}21.4 \\
\pm 1.3\end{array}$ & $\begin{array}{l}28.8 \\
\pm 2.1^{\mathrm{b}}\end{array}$ & $\begin{array}{l}141.7^{\mathrm{d}} \\
\pm 5.1^{\mathrm{d}}\end{array}$ & $\begin{array}{l}12.5 \\
\pm 3.1\end{array}$ & $\begin{array}{l}19.1 \\
\pm 2.0^{\mathrm{c}}\end{array}$ & $\begin{array}{l}92.8 \\
\pm 5.4^{\mathrm{b}}\end{array}$ & $\begin{array}{c}1.0 \\
\pm 1.0\end{array}$ & $\begin{array}{l}27.5 \\
\pm 6.8\end{array}$ & $\begin{array}{c}2.6 \\
\pm 0.6\end{array}$ & $\begin{array}{l}18.8 \\
\pm 4.7\end{array}$ & $\begin{array}{l}26.5 \\
\pm 2.5^{\mathrm{b}}\end{array}$ & $\begin{array}{c}6.9 \\
\pm 2.5\end{array}$ & $\begin{array}{l}18.2 \\
\pm 2.3^{\mathrm{b}}\end{array}$ & $\begin{array}{l}26.3 \\
\pm 3.4\end{array}$ & $\begin{array}{c}9.6 \\
\pm 1.5\end{array}$ & $\begin{array}{l}22.8 \\
\pm 7.1\end{array}$ & $\begin{array}{c}581.2 \\
\pm 31.8^{\mathrm{b}}\end{array}$ \\
\hline $\mathrm{BO} 2$ & $\begin{array}{r}103.6 \\
\pm 10.8^{\mathrm{b}}\end{array}$ & $\begin{array}{l}21.78 \\
\pm 3.3\end{array}$ & $\begin{array}{l}28.0 \\
\pm 4.7^{\mathrm{b}}\end{array}$ & $\begin{array}{l}155.0 \\
\pm 13.0^{\text {cd }}\end{array}$ & $\begin{array}{l}13.2 \\
\pm 3.2\end{array}$ & $\begin{array}{c}20.7 \\
\pm 2.8^{\mathrm{bc}}\end{array}$ & $\begin{array}{l}68.4 \\
\pm 8.1^{\mathrm{c}}\end{array}$ & $\begin{array}{c}1.6 \\
\pm 1.5\end{array}$ & $\begin{array}{l}26.5 \\
\pm 8.9\end{array}$ & $\begin{array}{c}2.8 \\
\pm 0.0\end{array}$ & $\begin{array}{l}18.7 \\
\pm 6.3\end{array}$ & $\begin{array}{l}28.6 \\
\pm 4.7^{\mathrm{b}}\end{array}$ & $\begin{array}{c}8.6 \\
\pm 1.3\end{array}$ & $\begin{array}{l}19.1 \\
\pm 3.9^{\mathrm{b}}\end{array}$ & $\begin{array}{l}29.6 \\
\pm 4.4\end{array}$ & $\begin{array}{l}10.6 \\
\pm 2.1\end{array}$ & $\begin{array}{c}23.4 \\
\pm 10.7\end{array}$ & $\begin{array}{l}580.0 \\
\pm 76.1^{\mathrm{c}}\end{array}$ \\
\hline PR3 & $\begin{array}{l}133.5 \\
\pm 9.8^{\mathrm{b}}\end{array}$ & $\begin{array}{l}26.4 \\
\pm 4.0\end{array}$ & $\begin{array}{l}35.1 \\
\pm 4.8^{\mathrm{b}}\end{array}$ & $\begin{array}{r}197.5 \\
\pm 15.7^{\mathrm{b}}\end{array}$ & $\begin{array}{l}16.7 \\
\pm 4.8\end{array}$ & $\begin{array}{c}24.0 \\
\pm 3.6^{\mathrm{bc}}\end{array}$ & $\begin{array}{l}96.0 \\
\pm 9.0^{\mathrm{b}}\end{array}$ & $\begin{array}{c}1.1 \\
\pm 1.0\end{array}$ & $\begin{array}{c}32.9 \\
\pm 10.6\end{array}$ & $\begin{array}{c}3.2 \\
\pm 0.9\end{array}$ & $\begin{array}{l}23.4 \\
\pm 8.1\end{array}$ & $\begin{array}{c}33.9 \\
\pm 6.3^{\text {ab }}\end{array}$ & $\begin{array}{c}9.8 \\
\pm 1.5\end{array}$ & $\begin{array}{l}23.3 \\
\pm 4.6^{\mathrm{b}}\end{array}$ & $\begin{array}{l}32.9 \\
\pm 5.4\end{array}$ & $\begin{array}{l}12.3 \\
\pm 2.4\end{array}$ & $\begin{array}{c}29.8 \\
\pm 10.7\end{array}$ & $\begin{array}{l}731.8 \\
\pm 82.1^{\mathrm{b}}\end{array}$ \\
\hline PF4 & $\begin{array}{l}128.9 \\
\pm 5.1^{\mathrm{b}}\end{array}$ & $\begin{array}{l}26.1 \\
\pm 2.7\end{array}$ & $\begin{array}{r}34.8 \\
\pm 2.9^{\mathrm{b}}\end{array}$ & $\begin{array}{c}177.4 \\
\pm 11.1^{\mathrm{bc}}\end{array}$ & $\begin{array}{l}16.1 \\
\pm 3.5\end{array}$ & $\begin{array}{c}24.4 \\
\pm 2.3^{\mathrm{bc}}\end{array}$ & $\begin{array}{l}107.3 \\
\pm 1.0^{\mathrm{b}}\end{array}$ & $\begin{array}{c}1.6 \\
\pm 1.5\end{array}$ & $\begin{array}{l}32.9 \\
\pm 6.8\end{array}$ & $\begin{array}{c}3.8 \\
\pm 1.4\end{array}$ & $\begin{array}{l}23.9 \\
\pm 4.0\end{array}$ & $\begin{array}{c}32.9 \\
\pm 2.9^{\mathrm{ab}}\end{array}$ & $\begin{array}{l}10.1 \\
\pm 1.0\end{array}$ & $\begin{array}{l}24.3 \\
\pm 2.1^{\mathrm{b}}\end{array}$ & $\begin{array}{l}31.5 \\
\pm 3.8\end{array}$ & $\begin{array}{l}12.3 \\
\pm 1.5\end{array}$ & $\begin{array}{l}23.3 \\
\pm 6.3\end{array}$ & $\begin{array}{r}710.4 \\
\pm 34.1^{\mathrm{b}}\end{array}$ \\
\hline DF5 & $\begin{array}{c}185.3 \\
\pm 34.5^{\mathrm{a}}\end{array}$ & $\begin{array}{l}32.1 \\
\pm 6.7\end{array}$ & $\begin{array}{l}43.6 \\
\pm 5.3^{\mathrm{a}}\end{array}$ & $\begin{array}{l}245.8 \\
\pm 29.6^{\mathrm{a}}\end{array}$ & $\begin{array}{l}17.0 \\
\pm 3.3\end{array}$ & $\begin{array}{l}30.3 \\
\pm 1.7^{\mathrm{a}}\end{array}$ & $\begin{array}{l}150.0 \\
\pm 4.8\end{array}$ & $\begin{array}{c}2.1 \\
\pm 0.9\end{array}$ & $\begin{array}{l}40.1 \\
\pm 7.3\end{array}$ & $\begin{array}{c}4.3 \\
\pm 1.2\end{array}$ & $\begin{array}{l}26.3 \\
\pm 7.7\end{array}$ & $\begin{array}{l}40.2 \\
\pm 7.1^{\mathrm{a}}\end{array}$ & $\begin{array}{l}10.3 \\
\pm 3.7\end{array}$ & $\begin{array}{l}31.1 \\
\pm 3.0^{\mathrm{a}}\end{array}$ & $\begin{array}{c}35.9 \\
\pm 15.0\end{array}$ & $\begin{array}{l}13.2 \\
\pm 3.4\end{array}$ & $\begin{array}{l}30.3 \\
\pm 7.9\end{array}$ & $\begin{array}{r}938.0 \\
\pm 33.2^{\mathrm{a}}\end{array}$ \\
\hline ST6 & $\begin{array}{l}125.5 \\
\pm 11.3^{\mathrm{b}}\end{array}$ & $\begin{array}{l}27.0 \\
\pm 4.4\end{array}$ & $\begin{array}{l}35.1 \\
\pm 5.5^{\mathrm{b}}\end{array}$ & $\begin{array}{c}182.6 \\
\pm 18.8^{\mathrm{bc}}\end{array}$ & $\begin{array}{c}16.4 \\
\pm 3.91\end{array}$ & $\begin{array}{l}24.7 \\
\pm 3.4^{\mathrm{b}}\end{array}$ & $\begin{array}{l}90.7 \\
\pm 8.3\end{array}$ & $\begin{array}{c}1.0 \\
\pm 1.1\end{array}$ & $\begin{array}{l}34.3 \\
\pm 7.5\end{array}$ & $\begin{array}{c}2.8 \\
\pm 0.6\end{array}$ & $\begin{array}{l}24.7 \\
\pm 4.5\end{array}$ & $\begin{array}{c}35.4 \\
\pm 4.8^{\mathrm{ab}}\end{array}$ & $\begin{array}{l}13.7 \\
\pm 4.5\end{array}$ & $\begin{array}{l}23.8 \\
\pm 3.5^{\mathrm{b}}\end{array}$ & $\begin{array}{l}33.9 \\
\pm 6.6\end{array}$ & $\begin{array}{l}13.0 \\
\pm 1.7\end{array}$ & $\begin{array}{c}30.1 \\
\pm 10.8\end{array}$ & $\begin{array}{r}714.6 \\
\pm 86.3^{\mathrm{b}}\end{array}$ \\
\hline F-value & $10.2^{* * 4)}$ & 2.8 & 4.9 & $13.4^{* *}$ & 0.9 & $6.1^{* *}$ & $15.5^{* *}$ & 0.3 & 1.1 & 1.4 & 0.8 & $2.9^{* *}$ & 2.0 & $5.7^{* *}$ & 0.6 & 1.3 & 0.5 & $13.3^{* * *}$ \\
\hline
\end{tabular}

${ }^{1)} \mathrm{RA} 1$, control (raw material), BO2, boiling, PR3, pan-roasting; PF4, stir-frying; DF5, deep-frying; ST6, steaming.

${ }^{2)}$ Values are Mean $\pm \mathrm{SD}(\mathrm{n}=3)$.

3)a-d Means with different superscripts in a row are significantly different by the Duncan's multiple range test $\mathrm{p}<0.05$.

${ }^{4}{ }^{*}<0.05,{ }^{* *} \mathrm{p}<0.01,{ }^{* * *} \mathrm{p}<0.001$.

아미노산의 파괴, 중합 손실 및 변성을 크게 일으키며, 헤테 로고리 등을 형성하게 되고, 라이시노알라닌 등 변이원성 아미노산을 형성하는 것으로 사료된다(Cho 등, 2017). 서 양요리에서는 굽거나 전자레인지 요리를 많이 하는 조리 법을 쓰며, 이것은 라이시노알라닌, 변이원성 페닐알라닌, 메티오닌 등 아미노산 변성물질인 발암원이 된다. 반면에 전통 한국의 전통 요리에서 기름에 볶거나 튀기는 조리법 은 일부 단백질과 아미노산만 변화가 일어나는 것으로 나타났다. 따라서 당근은 삶거나 찌는 전통적인 요리법이 아미노산의 영양소 잔존율을 높게 하며, 기름에 볶거나 튀기는 요리법을 사용하면 지용성 비타민이나 지방산 측 면에서 이로우나, 아미노산의 함량 변화가 크므로 아미노 산 변성 측면에서는 바람직한 조리법이 아니라고 여겨진 다. 당근의 잔존율을 고려할 때 스프, 찜과 국과 같이 습열 조리하는 방법이 잔존율을 유지하는 조리법으로 추천할 만하다. 본 연구 결과는 서리태, 서목태, 흑태, 백태 등 콩의 종류별 조리방법에 따른 아미노산 연구 결과에서 조리법에 따라 품종 간 Phe 등 함량의 차이가 크게 나타났 다. Met과 Cys 등과 같은 아미노산 함량 연구에서는 유의 차가 없다고 보고하였다(Lim 등, 2016).

\section{$\beta$-Carotene, 비타민 E 및 엽산}

당근의 조리법에 따른 여러 비타민의 함량을 Table 6 에 나타내었다. 당근은 주로 기름에 튀기면 $\beta$-carotene의 함량 이 생시료인 $1,977.2 \mathrm{mg} / 100 \mathrm{~g}$ 보다 $7,686.8 \mathrm{mg} / 100 \mathrm{~g}$ 으로 약 3.9 배 정도나 높아지는 것으로 나타났으며, 굽기에서
$5,128.73 \mathrm{mg} / 100 \mathrm{~g}$, 볶기에서도 $4,151 \mathrm{mg} / 100 \mathrm{~g}$ 으로 생시료 보다 현저하게 증가하는 경향을 보였다. 미국 USDA (https://www.healthline.com/health/beta-carotene-benefit, 2020)에 따르면 생당근의 경우, $8,285 \mathrm{mg} / 100 \mathrm{~g}(3.5$ ounce) 정도로 국내산 당근의 함량은 미국산보다 함량이 적게 나타났다. 이는 당근이 품종과 토양에 따라 함량이 다르기 때문으로 사료된다. 특히 모든 전통적인 요리법에서는 카 로티노이드의 함량이 생 시료보다 증가하는 경향을 보이 나, 수용성 조리법인 삶기와 찌기보다는 지용성 조리법인 볶기와 튀기기에서 그 함량이 현저히 증가하는 것으로 나타났다. 생당근은 삶거나 찌기 과정에서 $\beta$-carotene 함량 이 기름에 조리하였을 때보다 낮게 나타났으나 유의적인 차이는 없었다. 이는 당근에 많이 함유된 카로티노이드 성분은 시료 중에서 부위별 차이가 있고, 채소종류, 조리방 법, 종류×조리방법 순으로 영향을 받는다는 보고와 일치 하였기 때문으로 사료된다. 즉, 많은 카로티노이드 성분이 대두유 속에 들어있는 토코페롤의 영향으로 지용성인 기 름에 잘 유출되었기 때문에 튀기기에서는 유의적으로 증 가한 것이다. 이것은 고추와 파프리카와 같은 $\beta$-carotene 함량이 높은 녹황색채소의 튀기기에서 높은 함량을 보였 다는 보고와 유사하였다. 전자레인지에 조리하였을 때는 오히려 카로티노이드 함량이 감소하였다고 보고하였다 (Kim 등, 2017). 반면에 Ogunlesi와 Lee 등(1999)의 연구에 서 당근을 통조림을 하면 카로티노이드 성분이 $22 \%$ 정도 까지 감소한다고 보고하였다. 또한, cis-isomers의 형성도 적게 나타났다고 보고되었다. 이는 trans- $\beta$-carotene의 함량 
Table 6. Vitamin contents of carrots by different cooking conditions

(unit: $\mathrm{mg} / 100 \mathrm{~g}$ )

\begin{tabular}{|c|c|c|c|c|c|c|c|}
\hline $\begin{array}{l}\text { Cooking } \\
\text { methods }\end{array}$ & $\beta$-Carotene & $\alpha$-Tocopherol & $\beta$-Tocopherol & $\gamma$-Tocopherol & $\delta$-Tocopherol & Total vitamin $\mathrm{E}$ & Folic acid \\
\hline $\mathrm{RA}^{1)}$ & $1,977.2 \pm 513.9^{2) \mathrm{d} 3)}$ & $0.5 \pm 0.2^{\mathrm{c}}$ & $0.2 \pm 0.1^{\mathrm{b}}$ & - & - & $0.5 \pm 0.5$ & $18.8 \pm 6.5$ \\
\hline $\mathrm{BO} 2$ & $3,642.8 \pm 793.4^{\mathrm{c}}$ & $0.7 \pm 0.12^{\mathrm{bc}}$ & $0.2 \pm 0.0^{\mathrm{b}}$ & - & - & $0.7 \pm 0.6$ & $17.3 \pm 4.5$ \\
\hline PR3 & $5,128.7 \pm 766.1^{\mathrm{b}}$ & $0.8 \pm 0.2^{\mathrm{abc}}$ & $0.3 \pm 0.0^{\mathrm{b}}$ & - & - & $0.8 \pm 0.7$ & $18.3 \pm 1.4$ \\
\hline PF4 & $4,151.1 \pm 887.3^{\mathrm{bc}}$ & $1.3 \pm 0.6^{\mathrm{ab}}$ & $0.3 \pm 0.1^{\mathrm{ab}}$ & $1.6 \pm 0.2^{\mathrm{b}}$ & $0.4 \pm 0.1^{\mathrm{b}}$ & $2.6 \pm 2.1$ & $19.0 \pm 2.8$ \\
\hline DF5 & $7,686.8 \pm 368.5^{\mathrm{a}}$ & $1.4 \pm 0.4^{\mathrm{a}}$ & $0.4 \pm 0.1^{\mathrm{a}}$ & $2.0 \pm 0.3^{\mathrm{a}}$ & $0.4 \pm 0.1^{\mathrm{a}}$ & $3.3 \pm 2.5$ & $25.2 \pm 10.9$ \\
\hline ST6 & $3,879.5 \pm 677.1^{\mathrm{bc}}$ & $0.7 \pm 0.2^{\mathrm{bc}}$ & $0.2 \pm 0.1^{\mathrm{b}}$ & - & - & $0.7 \pm 0.6$ & $19.4 \pm 5.5$ \\
\hline F-value & $22.7^{* * * 4)}$ & $3.8^{*}$ & 3.0 & $161.9^{* * *}$ & $42.5^{* * *}$ & 2.1 & 0.6 \\
\hline
\end{tabular}

${ }^{1)} \mathrm{RA} 1$, control (raw material); BO2, boiling; PR3, pan-roasting; PF4, stir-frying; DF5, deep-frying; ST6, steaming. ${ }^{2)}$ Values are Mean $\pm \mathrm{SD}(\mathrm{n}=3)$.

3)a-d Means with different superscripts in a row are significantly different by the Duncan's multiple range test $\mathrm{p}<0.05$.

${ }^{4)} \mathrm{p}<0.05,{ }^{* *} \mathrm{p}<0.01,{ }^{* * *} \mathrm{p}<0.001$.

을 증가시키나, lutein의 함량은 감소시키기 때문이라고 알려져 있다. 반면에 당근을 물속에서 33분간 조리하면 $23 \%$ 이상 그 함량이 증가한다고 보고와 유사하였다 (Granado 등, 1992). 따라서 당근을 삶으면 카로티노이드의 손실이 적으며, 이는 홍고추를 삶았을 때와 유사한 결과를 보였다. 반면에 식물성인 당근 중에는 동물성인 레티놀 성분은 검출되지 않아 본 논문에서는 제시하지 않았다. $\alpha$-tocopherol 성분은 튀기기에서 유의적으로 높게 나타났 고 볶기 순으로 나타났다. 굽기, 찌기, 삶기 순으로 나타났 으며, $\beta$-tocopherol도 유사한 경향으로 나타났다. 특히 $\gamma$ -tocopherol과 $\delta$-tocopherol은 튀기기에서 유의적으로 증가 하는 경향을 나타내었고, 볶기에서도 유의적으로 증가하 였다. 그러나 굽기, 찌기, 삶기 과정에서는 전혀 검출되지 않았다. 이는 기름 성분에서 유래한 토코페롤의 영향 때문 으로 당근은 기름에 볶는 요리가 비타민 $\mathrm{E}$ 의 좋은 급원이 된다고 여겨진다. 항산화 영양소인 총 비타민 $\mathrm{E}$ 의 함량은 볶기, 튀기기에서 다소 높게 나타났으나 생시료와 찌기, 굽기, 찌기 등에서 유의차가 없었는데, 이는 기름 함량의 차이에 따른 시료 간 편차가 컸기 때문이라고 사료된다. 각종 조리에서 비타민과 무기질의 잔존율이 대체로 높아 진다는 보고(Ann, 1999)와 유사하였다.

조리방법에 따른 엽산의 함량은 생시료가 $18.8 \mathrm{mg} / 100$ $\mathrm{g}$, 삶기에서 $17.3 \mathrm{mg} / 100 \mathrm{~g}$, 굽기, 볶기에서 $18.3-19.0$ $\mathrm{mg} / 100 \mathrm{~g}$ 을 나타내었고, 튀기기에서 $25.2 \mathrm{mg} / 100 \mathrm{~g}$ 으로 비교적 증가하는 경향을 보였고, 찌기에서는 $19.4 \mathrm{mg} / 100$ $\mathrm{g}$ 으로 조리 방법을 달리하여도 유의적인 차이를 나타나지 않았다. 이는 홍고추 등은 삶기에서 엽산의 잔존율이 가장 높았다는 결과와는 차이가 있었고, 버섯류에서는 엽산의 잔존율이 튀기기에서 가장 높았다는 결과와 유사하게 나 타났다(Kim, 2016; Kim, 2017). 버섯(표고, 느타리, 양송이)
은 시료 간 유의차가 큰(Park 등, 2017) 반면에 당근은 시료 간 표준편차가 너무 크므로 조리방법에 따른 유의차가 없었다.

\section{조리가공계수}

당근의 조리과정에 의해 변화하는 조리가공계수를 Table 7에 나타내었다. 모든 조리방법에 따라 가공계수는 유의적인 차이를 나타냈다 $(\mathrm{p}<0.05)$. 조리 후 중량의 감소 로 인하여 당근의 부피가 줄어 보수력이 감소하게 되며, 이것은 중량감소로 나타나 조리시간과 요리하는 동안의 온도에 따라 감소량이 크게 나타났다. 당근은 조리방법에 따라 각각 튀기기는 $54 \%$, 굽기는 $17 \%$, 볶기는 $13 \%$, 찌기는 $9 \%$, 삶기는 약 $8 \%$ 정도의 중량이 감소하는 것으로 나타났

Table 7. The weight (\%) of carrots by different cooking methods

\begin{tabular}{ccc}
\hline $\begin{array}{c}\text { Cooking } \\
(\mathrm{mg} / 100 \mathrm{~g})\end{array}$ & Cooking method & Weight $(\%)$ \\
\hline RA1 & Raw sample & $100.0 \pm 0.0^{2) \mathrm{a} 3)}$ \\
BO2 & Boiled sample & $92.0 \pm 0.7^{\mathrm{b}}$ \\
PR3 & Pan roasted sample & $83.0 \pm 1.0^{\mathrm{d}}$ \\
PF4 & Pan fried sample & $86.0 \pm 0.5^{\mathrm{c}}$ \\
DF5 & Deep fried sample & $46.4 \pm 2.1^{\mathrm{e}}$ \\
ST6 & Steamed sample & $91.0 \pm 0.7^{\mathrm{b}}$ \\
\hline F-value & & 480.4 \\
\hline
\end{tabular}

${ }^{1)} \mathrm{RA} 1$, control (raw material); BO2, boiling; PR3, pan-roasting; PF4, stir-frying; DF5, deep-frying; ST6, steaming.

${ }^{2)}$ Values are Mean $\pm \mathrm{SD}(\mathrm{n}=3)$.

3)-e- Means with different superscripts in a row are significantly different by the Duncan's multiple range test $\mathrm{p}<0.05$. 
다. 특히 모든 조리 방법 중 가공계수는 특히 튀기기가 가장 적은 $46.36 \%$ 로 나타났으며, 이것은 국내산 삼겹살을 오븐에서 구웠을 때 가열감량이 $42 \%$ 정도라는 Yang 등 (2009)의 보고와 비슷한 결과이다. 삶기와 찌기 간에는 중량 감소의 유의차가 없었고, 나머지 볶기에서도 모두 중량이 유의적으로 감소하는 경향을 보였다. 이는 Park 등(2017)의 연구에서도 튀기기의 가공계수가 가장 낮게 나타나는 것으로 보고되었다. 또한, 여러 연구에서 튀기기 를 제외한 조리방법에 의해 75-95\%의 조리가공계수가 나타나는 것으로 확인되어 본 연구와 Kim 등(2016)과 Suh 등(1998)의 보고와 유사한 경향을 나타내었다. 데이터 값 의 차이는 재료 및 조리시간 차이에 의한 것으로 보인다. 특히 이 가공계수의 무게 $(\%)$ 는 Table 8 의 수분 잔존율과 거의 유사한 경향을 나타내었다.

\section{영양성분잔존율}

\section{수분, 단백질, 지방, 탄수화물, 회분, 식이섬유}

여러 가지 조리방법에 따라 조리한 당근의 수분, 단백질, 지방, 탄수화물, 회분의 잔존율은 Table 8 에 나타내었다. 수분함량은 삶기를 한 시료에서 $92.3 \%$ 로 가장 높게 나타났 으며, 생시료보다 수분함량이 높았고, 찌기를 한 시료에서 도 $90.9 \%$ 의 높은 수분을 함유하고 있었다. 반면에, 팬에 굽기(77.5\%), 기름에 볶으면 $81.5 \%$, 기름에 튀기면 $40.9 \%$ 로 잔존율이 현저하게 감소하는 것으로 나타났다. 튀기기 를 했을 때 단백질과 수분의 잔존율이 낮은 값을 나타내는 것을 확인하였고, 찌기를 했을 때 지방의 잔존율이 크게 낮아지는 것으로 나타났다. 탄수화물의 손실은 삶기는 조 리수에 의한 손실, 튀기기에서는 기름으로의 손실과 Maillard 반응에 의한 것으로 판단된다. 일반적인 조리 시 시간과 $100^{\circ} \mathrm{C}$ 이상의 온도에서는 유리 아미노기와 카르보
닐 화합물 간의 Maillard 반응으로 당과 아미노기의 함량이 감소된다고 알려져 있다(Xu, 2019; Sanz-Serrano, 2020).

\section{무기질}

당근의 조리법에 따른 무기질 및 아미노산의 잔존율을 Table 9에 나타내었다. 무기질은 종류에 따라서 약간의 차이가 있지만, 삶기를 할 경우 $\mathrm{K}$ 과 $\mathrm{Fe}$ 이, 튀기기를 했을 때는 $\mathrm{Na}(67.5 \%), \mathrm{Fe}(54.0 \%)$ 및 $\mathrm{Cu}$ 의 잔존율은 $68.4 \%$ 로 낮 게 나타났지만, 비교적 조리 후에 $70 \%$ 이상의 높은 잔존율 을 나타내었다. $\mathrm{P}$ 은 삶거나 $(72.5 \%)$ 튀길 때 $(80.2 \%)$ 로 용출 되는 함량이 많은 것으로 나타났다. $\mathrm{K}$ 은 삶기 $(67.1 \%)$ 에서 가장 많이 용출되며, 나머지 조리법에서는 유의차가 없었 다. 이것은 무기질은 일반적으로 열에 안정하여 열에 의한 손실을 적지만 습식조리를 통해서는 무기질의 손실이 많 아진다고 알려져 있고, 특히 $\mathrm{K}$ 은 다른 조리법에 비해 삶는 과정 $(67.1 \%)$ 에서 용출이 가장 많다고 알려져 있어서 본 연구와 유사한 결과를 보이고 있다(Oh 등, 1996).

\section{아미노산}

당근의 조리법에 따른 무기질 및 아미노산의 잔존율을 Table 10 에 나타내었다. 아미노산은 조리과정에 의한 잔존 율의 변화가 크게 나타나지 않았다. 볶기의 경우 $\mathrm{Arg}$ $(88.7 \%)$ 이 낮게 나타났고, 나머지 아미노산은 모두 $100 \%$ 이상의 높은 잔존율을 보였지만, 튀기기를 하였을 때 $61.6 \%(\mathrm{Arg})-94.0 \%(\mathrm{Cys})$ 의 잔존율을 나타내어 다른 조리 방법에 비해 매우 낮았다. 튀기기의 아미노산의 잔존율은 단백질 잔존율 감소로 인한 것으로 당과 아미노산의 Maillard 반응에도 영향을 줄 것이다. 특히, 튀기기는 볶기 보다 아미노산의 잔존율이 더 낮게 나타났다. 삶기, 튀기기 는 총 아미노산의 잔존율이 감소하는 경향을 보였고, 이는 수용성 아미노산이 수중에 용출되어 시료 중 잔존율이

Table 8. Retention rates of proximate components (\%) in carrots after cooking

(unit: $\mathrm{mg} / 100 \mathrm{~g}$ )

\begin{tabular}{|c|c|c|c|c|c|}
\hline Cooking & Carbohydrate & Protein & Total fat & Moisture & Ash \\
\hline RA1 & $100.0 \pm 0.0^{2) \mathrm{ab} 3)}$ & $100.0 \pm 0.0^{\mathrm{a}}$ & $100.0 \pm 0.0^{\mathrm{d}}$ & $100.0 \pm 0.0^{\mathrm{a}}$ & $100.0 \pm 0.0^{\mathrm{a}}$ \\
\hline $\mathrm{BO} 2$ & $69.2 \pm 14.4^{\mathrm{c}}$ & $85.3 \pm 2.7^{\mathrm{b}}$ & $367.1 \pm 117.8^{c}$ & $92.1 \pm 0.1^{\mathrm{b}}$ & $74.5 \pm 9.9^{\mathrm{b}}$ \\
\hline PR3 & $120.3 \pm 18.1^{\mathrm{a}}$ & $100.5 \pm 2.0^{\mathrm{a}}$ & $175.5 \pm 0.0^{\mathrm{d}}$ & $77.5 \pm 0.1^{\mathrm{e}}$ & $105.3 \pm 15.3^{\mathrm{a}}$ \\
\hline PF4 & $95.3 \pm 18.1^{\mathrm{b}}$ & $104.1 \pm 5.3^{\mathrm{a}}$ & $1,262.5 \pm 133.6^{\mathrm{a}}$ & $81.5 \pm 0.1^{\mathrm{d}}$ & $101.7 \pm 7.7^{\mathrm{a}}$ \\
\hline DF5 & $68.3 \pm 6.5^{c}$ & $67.4 \pm 0.4^{\mathrm{c}}$ & $1,009.0 \pm 160.4^{\mathrm{b}}$ & $40.9 \pm 0.1^{\mathrm{f}}$ & $76.0 \pm 6.2^{b}$ \\
\hline ST6 & $107.1 \pm 10.2^{\mathrm{ab}}$ & $102.1 \pm 1.7^{\mathrm{a}}$ & $25.4 \pm 18.8^{\mathrm{d}}$ & $90.6 \pm 0.1^{\mathrm{c}}$ & $98.6 \pm 14.6^{\mathrm{a}}$ \\
\hline F-value & 7.7 & 88.3 & 84.0 & $162,260.1$ & 5.3 \\
\hline
\end{tabular}

${ }^{1}$ RA1, control (raw material); BO2, boiling; PR3, pan-roasting; PF4, stir-frying; DF5, deep-frying; ST6, steaming.

${ }^{2)}$ Values are Mean $\pm \mathrm{SD}(\mathrm{n}=3)$.

3)a-f Means with different superscripts in a row are significantly different by the Duncan's multiple range test $\mathrm{p}<0.05$. 
Table 9. Retention rates of mineral contents (\%) in carrots after cooking

(unit: $\mathrm{mg} / 100 \mathrm{~g}$ )

\begin{tabular}{ccccccccccc}
\hline Cooking & $\mathrm{Na}$ & $\mathrm{K}$ & $\mathrm{Ca}$ & $\mathrm{Fe}$ & $\mathrm{P}$ & $\mathrm{Mg}$ & $\mathrm{Mn}$ & $\mathrm{Se}$ & $\mathrm{Cu}$ & $\mathrm{Zn}$ \\
\hline RA1 & $100.0 \pm 0.0^{2 \mathrm{~b} 3)}$ & $100.0 \pm 0.0^{\mathrm{a}}$ & $100.0 \pm 0.0^{\mathrm{ab}}$ & $100.0 \pm 0.0$ & $100.0 \pm 0.0^{\mathrm{a}}$ & $100.0 \pm 0.0^{\mathrm{c}}$ & $100.0 \pm 0.0^{\mathrm{b}}$ & $100.0 \pm 0.0$ & $100.0 \pm 0.0^{\mathrm{ab}}$ & $100.0 \pm 0.0^{\mathrm{ab}}$ \\
BO2 & $84.1 \pm 7.8^{\mathrm{c}}$ & $67.1 \pm 12.5^{\mathrm{b}}$ & $91.0 \pm 6.4^{\mathrm{bc}}$ & $68.3 \pm 25.4$ & $80.2 \pm 4.1^{\mathrm{b}}$ & $81.1 \pm 2.7^{\mathrm{d}}$ & $91.3 \pm 17.3^{\mathrm{b}}$ & $105.6 \pm 34.2$ & $116.6 \pm 33.9^{\mathrm{a}}$ & $83.1 \pm 12.7^{7^{\mathrm{c}}}$ \\
PR3 & $112.2 \pm 7.6^{\mathrm{a}}$ & $101.6 \pm 13.4^{\mathrm{a}}$ & $111.0 \pm 8.4^{\mathrm{a}}$ & $75.2 \pm 23.2$ & $101.5 \pm 6.1^{\mathrm{a}}$ & $131.2 \pm 5.9^{\mathrm{a}}$ & $126.6 \pm 12.8^{\mathrm{a}}$ & $100.0 \pm 26.3$ & $132.9 \pm 22.5^{\mathrm{a}}$ & $109.6 \pm 14.9^{\mathrm{a}}$ \\
PF4 & $80.5 \pm 3.3^{\mathrm{c}}$ & $110.8 \pm 18.8^{\mathrm{a}}$ & $111.5 \pm 8.5^{\mathrm{a}}$ & $83.6 \pm 35.8$ & $98.5 \pm 2.3^{\mathrm{a}}$ & $113.3 \pm 2.8^{\mathrm{b}}$ & $146.2 \pm 0.9^{\mathrm{a}}$ & $100.0 \pm 8.6$ & $101.8 \pm 4.9^{\mathrm{ab}}$ & $110.3 \pm 14.9^{\mathrm{a}}$ \\
DF5 & $67.5 \pm 3.0^{\mathrm{d}}$ & $88.1 \pm 3.6^{\mathrm{ab}}$ & $80.4 \pm 4.2^{\mathrm{b}}$ & $54.0 \pm 17.5$ & $72.5 \pm 5.6^{\mathrm{b}}$ & $88.1 \pm 4.1^{\mathrm{d}}$ & $94.2 \pm 7.8^{\mathrm{b}}$ & $81.9 \pm 13.6$ & $68.4 \pm 10.5^{\mathrm{b}}$ & $75.5 \pm 13.6^{\mathrm{c}}$ \\
ST6 & $95.5 \pm 8.4^{\mathrm{b}}$ & $97.6 \pm 17.0^{\mathrm{a}}$ & $103.9 \pm 7.9^{\mathrm{c}}$ & $71.1 \pm 26.3$ & $104.0 \pm 10.6^{\mathrm{a}}$ & $109.9 \pm 5.5^{\mathrm{b}}$ & $137.7 \pm 15.0^{\mathrm{a}}$ & $100.7 \pm 28.6$ & $104.9 \pm 14.8^{\mathrm{a}}$ & $98.0 \pm 9.1^{\mathrm{ab}}$ \\
\hline F-value & 21.73 & 4.18 & 10.07 & 1.25 & 15.20 & 61.6 & 13.6 & 0.4 & 4.1 & 4.1 \\
\hline
\end{tabular}

${ }^{1)} \mathrm{RA} 1$, control (raw material); BO2, boiling; PR3, pan-roasting; PF4, stir-frying; DF5, deep-frying; ST6, steaming.

${ }^{2)}$ Values are Mean \pm SD $(n=3)$.

${ }^{3) a-d}$ Means with different superscripts in a row are significantly different by the Duncan's multiple range test $\mathrm{p}<0.05$.

Table 10. Retention rates of amino acid contents (\%) in carrots after cooking

(unit: $\mathrm{mg} / 100 \mathrm{~g}$ )

\begin{tabular}{|c|c|c|c|c|c|c|c|c|c|c|c|c|c|c|c|c|c|c|}
\hline ooking & Asp & Thre & Ser & Glu & Pro & Gly & la & Cys & Val & Jet & Ile & el & Tyr & Phe & Lys & His & rg & $\begin{array}{c}\text { Total } \\
\text { aa }\end{array}$ \\
\hline RA & \pm 0.0 & & & & $\begin{array}{c}100.0 \\
\pm 0.0\end{array}$ & $\pm 0.0^{\mathrm{a}}$ & & & & & & $\begin{array}{l}100.0 \\
\pm 0.0^{\mathrm{a}}\end{array}$ & & & & $\begin{array}{l}00.0 \\
0.0^{\mathrm{a}}\end{array}$ & & $\pm 0.0^{\mathrm{ab}}$ \\
\hline $\mathrm{BC}$ & & & & & & & $\begin{array}{c}67.6 \\
\pm 8.0^{\mathrm{d}}\end{array}$ & & & & & & & & & & & $\begin{array}{c}91.6 \\
\pm 12.0^{\mathrm{b}}\end{array}$ \\
\hline $\mathrm{PF}$ & & & $\begin{array}{r}97 \\
\pm 13\end{array}$ & & $\begin{array}{l}10 \\
\pm 3\end{array}$ & $\begin{array}{l}10 \\
\pm 1\end{array}$ & $\begin{array}{c}83.1 \\
\pm 7.8^{\mathrm{bc}}\end{array}$ & & $\begin{array}{c}96.0 \\
\pm 30.8\end{array}$ & & & & $8^{\mathrm{bc}}$ & .1 & & & $\begin{array}{l}5.0 \\
7.6\end{array}$ & $\begin{array}{r}101.2 \\
\pm 11.4^{\mathrm{ab}}\end{array}$ \\
\hline $\mathrm{PF}$ & & & $\begin{array}{l}105.0 \\
\pm 8.6^{\mathrm{a}}\end{array}$ & $\begin{array}{l}108.8 \\
\pm 6.8^{\mathrm{ab}}\end{array}$ & $\begin{array}{l}111 \\
\pm 24\end{array}$ & $\begin{array}{r}106.3 \\
\pm 10.4^{\mathrm{a}}\end{array}$ & $\begin{array}{l}100.5 \\
\pm 0.9^{\mathrm{a}}\end{array}$ & $\begin{array}{r}14 \\
\pm 12\end{array}$ & $\begin{array}{l}10 \\
\pm 2\end{array}$ & $\begin{array}{l}126.7 \\
\pm 46.6\end{array}$ & $\begin{array}{c}11 \\
\pm 18\end{array}$ & $\begin{array}{l}107.7 \\
\pm 9.5^{\mathrm{a}}\end{array}$ & & $\begin{array}{l}116.4 \\
\pm 10.0\end{array}$ & .3 & & $\begin{array}{c}88.7 \\
\pm 23.9\end{array}$ & $\begin{array}{l}106.3 \\
\pm 5.1^{\mathrm{ab}}\end{array}$ \\
\hline DF5 & $\begin{array}{r}82 \\
\pm 15\end{array}$ & $\begin{array}{c}69.7 \\
\pm 14.5^{\mathrm{b}}\end{array}$ & $\begin{array}{c}70.2 \\
\pm 8.5^{\mathrm{b}}\end{array}$ & $\begin{array}{l}0.4 \\
\pm 9.7^{\mathrm{c}}\end{array}$ & $\begin{array}{c}63.0 \\
\pm 12.1\end{array}$ & $\begin{array}{c}73.5 \\
\pm 4.1^{\mathrm{b}}\end{array}$ & $\begin{array}{c}74.9 \\
\pm 12.4^{\text {cd }}\end{array}$ & $\begin{array}{c}94.0 \\
\pm 90.3\end{array}$ & $\begin{array}{c}6 \\
\pm 1\end{array}$ & $\begin{array}{c}7 \\
\pm 2\end{array}$ & $\begin{array}{r}65.0 \\
\pm 18.9^{\mathrm{b}}\end{array}$ & $\begin{array}{c}70.3 \\
\pm 12.3^{b}\end{array}$ & $\begin{array}{r}6 \\
\pm 2\end{array}$ & $\begin{array}{l}4 \\
5\end{array}$ & $\begin{array}{r}6 \\
\pm 2\end{array}$ & & $\begin{array}{c}6 \\
\pm\end{array}$ & $\begin{array}{l}74.8 \\
\pm 2.7^{\mathrm{c}}\end{array}$ \\
\hline ST6 & $\begin{array}{l}109.8 \\
\pm 9.9^{\mathrm{a}}\end{array}$ & $\begin{array}{c}115.7 \\
\pm 18.8^{\mathrm{a}}\end{array}$ & $\begin{array}{l}111.7 \\
\pm 17.5^{\mathrm{a}}\end{array}$ & $\begin{array}{l}118.1 \\
\pm 12.1^{\mathrm{a}}\end{array}$ & $\begin{array}{l}120.1 \\
\pm 28.6\end{array}$ & $\begin{array}{r}118.5 \\
\pm 16.0^{\mathrm{a}}\end{array}$ & $\begin{array}{c}89.6 \\
\pm 8.2^{\mathrm{ab}}\end{array}$ & $\begin{array}{c}95.5 \\
\pm 97.8\end{array}$ & $\begin{array}{l}114.3 \\
\pm 24.8\end{array}$ & $\begin{array}{c}99.5 \\
\pm 20.1\end{array}$ & $\begin{array}{c}120.4 \\
\pm 22.0^{\mathrm{a}}\end{array}$ & $\begin{array}{c}122.1 \\
\pm 16.5^{\mathrm{a}}\end{array}$ & $\begin{array}{r}181.4 \\
\pm 59.5^{\mathrm{a}}\end{array}$ & $\begin{array}{l}119.9 \\
\pm 17.8\end{array}$ & $\begin{array}{l}118.2 \\
\pm 23.0^{\mathrm{a}}\end{array}$ & $\begin{array}{c}124.3 \\
\pm 16.1^{\mathrm{a}}\end{array}$ & $\begin{array}{l}121.0 \\
\pm 43.3\end{array}$ & $\begin{array}{r}112.7 \\
\pm 13.6^{\mathrm{a}}\end{array}$ \\
\hline F-value & 4 & 3 & 4.5 & 7.153 & 2.352 & 4. & 9.2 & 0 & 1 & 0 & 2 & 4. & 5 & 3 & 3.2 & 4 & 1.8 & 6.4 \\
\hline
\end{tabular}

${ }^{1)}$ RA1, control (raw material); BO2, boiling; PR3, pan-roasting; PF4, stir-frying; DF5, deep-frying; ST6, steaming.

${ }^{2)}$ Values are Mean $\pm \mathrm{SD}(\mathrm{n}=3)$.

${ }^{3) a-d}$ Means with different superscripts in a row are significantly different by the Duncan's multiple range test $\mathrm{p}<0.05$.

낮아졌기 때문으로 사료된다. 갓김치의 경우 숙성되면서 포도당과 과당은 감소한다고 보고되었는데, 글루탐산, 알 라닌과 시스틴 등 지미 아미노산 성분이 유의적으로 증가 하였다고 보고되었다. 김치는 젓갈 중 아미노산의 증가로 숙성 후 더 맛이 좋아지나 튀기기를 하면 이러한 아미노산 의 변성 등으로 잔존율이 현저하게 감소하는 것으로 사료 된다(Cho, 1993; Jang, 2016; Cho, 2017).

\section{$\beta$-Carotene, $a$-tocopherol, vitamin $E$ 및 folate}

당근의 $\beta$-carotene, $\alpha$-tocopherol, Vitamin E, folate 잔존율 을 Table 11에 나타내었다. $\beta$-carotene과 tocopherol과 Vit $\mathrm{E}$ 는 매우 높은 잔존율을 보였으나, 엽산(folate)의 경우 튀
기기 과정에서 $61.96 \%$ 의 낮은 잔존율을 보이고, 찌기를 이후 $94.52 \%$ 로 높은 잔존율을 보였지만 조리방법 간 유의 적인 차이는 없었다. $\mathrm{Kim}$ 등(2017)은 색깔별 파프리카와 피망의 조리방법에 따라 비타민 잔존율 연구에서 시료의 특성과 조리방법 및 시간에 따라 $\beta$-carotene, Vit E, 엽산 (folate)의 잔존율이 유의차가 크다고 보고하였다. $\beta$ Carotene의 경우 일부 채소를 제외하고 데치는 과정에서 높은 잔존율을 보였으며(Hwang 등, 2016), 볶거나 튀기는 과정에서 기름에 함유되어 있는 tocopherol에 의해 비타민 $\mathrm{E}$ 함량이 전반적으로 증가하는 것으로 알려져 있다 (National Institute of Agricultural Sciences, RDA, 2006). 당 근도 조리방법에 따라 비타민 $\mathrm{E}$ 의 잔존율이 높아지는 반 
Table 11. Retention rates of vitamin contents (\%) in carrots after cooking

\begin{tabular}{cccccc}
\hline Cooking & $\beta$-Carotene $(\%)$ & $\alpha$-Tocopherol $(\%)$ & $\beta$-Tocopherol $(\%)$ & Total vitamin E $(\%)$ & Folate $(\%)$ \\
\hline RA1 & $100.0 \pm 0.0^{2)}$ & $100.0 \pm 0.0$ & $100.0 \pm 0.0$ & $100.0 \pm 0.0^{\mathrm{c} 3)}$ & $100.0 \pm 0.0$ \\
BO2 & $114.2 \pm 33.5$ & $138.4 \pm 24.7$ & $111.6 \pm 14.6$ & $168.9 \pm 7.1^{\mathrm{c}}$ & $84.1 \pm 21.8$ \\
PR3 & $124.9 \pm 32.9$ & $140.4 \pm 31.6$ & $107.5 \pm 14.0$ & $173.2 \pm 5.0^{\mathrm{c}}$ & $78.1 \pm 6.6$ \\
PF4 & $189.8 \pm 77.2$ & $246.5 \pm 116.3$ & $144.8 \pm 48.7$ & $609.8 \pm 154.8^{\mathrm{a}}$ & $87.6 \pm 13.1$ \\
DF5 & $116.0 \pm 16.0$ & $140.9 \pm 35.6$ & $94.6 \pm 24.7$ & $399.1 \pm 11.6^{\mathrm{b}}$ & $62.0 \pm 26.9$ \\
ST6 & $128.4 \pm 22.4$ & $147.8 \pm 38.5$ & $112.2 \pm 26.4$ & $187.0 \pm 14.9^{\mathrm{c}}$ & $94.5 \pm 26.7$ \\
\hline F-value & 2.0 & 2.4 & 1.4 & 23.1 & 1.5 \\
\hline
\end{tabular}

${ }^{1}$ RA1, control (raw material); BO2, boiling; PR3, pan-roasting; PF4, stir-frying; DF5, deep-frying; ST6, steaming.

${ }^{2)}$ Values are Mean $\pm \mathrm{SD}(\mathrm{n}=3)$.

${ }^{3)-c}$ Means with different superscripts in a row are significantly different by the Duncan's multiple range test $\mathrm{p}<0.05$.

면에 엽산은 주로 잎 등에 많이 존재하는 영양소로 고추와 파프리카의 조리방법과는 다르게 당근은 뿌리채소로 시 료 간 차이와 조리방법의 유의차가 적은 것으로 사료된다 (Stea 등, 2007).

\section{요 약}

모든 조리방법에 따라 가공계수는 유의적인 차이를 나 타냈다 $(\mathrm{p}<0.05)$. 조리 후 중량의 감소로 인하여 당근의 부 피가 줄어 보수력이 감소하게 되며, 이것은 중량감소로 나타나 조리시간과 요리하는 동안의 온도에 따라 감소량 이 크게 나타났다. 조리과정에 의해 변화하는 당근의 조리 가공계수를 나타내었다. 당근은 조리방법에 따라 각각 튀 기기는 $54 \%$, 굽기는 $17 \%$, 볶기는 $13 \%$, 찌기는 $9 \%$, 삶기는 약 $8 \%$ 정도의 중량이 감소하는 것으로 나타났다. 조리방 법에 따른 당근의 수분함량은 삶기를 한 시료에서 $92.3 \%$ 로 가장 높게 나타났으며, 생시료보다 수분함량이 높았고 찌기와 삶기에서도 유의적으로 감소하였으나, 팬에 굽기 거나 기름에 볶으면 각각 $77.5 \%, 81.5 \%$ 였고, 기름에 튀기 면 $40.9 \%$ 로 잔존율이 더 현저하게 감소하였다. 튀기기를 했을 때 단백질과 수분의 잔존율이 낮은 값을 나타내었고, 찌기는 지방의 잔존율이 크게 낮아지는 것으로 나타났다. 탄수화물의 손실은 삶기는 조리수에 의한 손실, 튀기기에 서는 기름으로의 인한 수분 손실과 Maillard 반응 등에 의한 것으로 사료된다. 무기질은 종류에 따라서 약간의 차이가 있지만, 삶기를 하면 $\mathrm{K}$ 과 $\mathrm{Fe}$ 이 낮고, 튀기기를 했을 때는 $\mathrm{Na}, \mathrm{Fe}$ 과 $\mathrm{Cu}$ 의 잔존율이 낮게 나타났지만, 비교적 조리 후 $70 \%$ 이상의 높은 잔존율을 나타내었다. 아미노산 은 조리과정에 의한 잔존율의 변화가 크게 나타나지 않았 다. 볶기의 경우 $\operatorname{Arg}(88.7 \%)$ 를 제외하고 모두 $100 \%$ 이상의 높은 잔존율 값을 보였지만, 튀기기를 하였을 때 $61.6 \%(\mathrm{Arg})$
- 94.0\%(Cys)의 잔존율을 나타내어 다른 조리방법에 비해 매우 낮았다. 습열 요리는 아미노산의 잔존율이 비교적 높은 조리법으로 나타났다. 영양소 함량 중 특히 $\mathrm{Na}$ 의 함량은 $125.7 \mathrm{mg} / 100 \mathrm{~g}$ 으로 튀기기를 하면 가장 높게 나타 났으며, 물에 삶기 $(79.14 \mathrm{mg} / 100 \mathrm{~g})$ 나 찌기 $(89.9 \mathrm{mg} / 100$ $\mathrm{g}$ )를 하는 조리법이 $\mathrm{Na}$ 함량을 줄이는 데 큰 도움을 주는 조리법으로 나타났다 $(\mathrm{p}<0.001)$. 당근은 주로 기름에 튀기 면 $\beta$-carotene의 함량이 생시료인 $1,977.2 \mathrm{mg} / 100 \mathrm{~g}$ 보다 $7,686.75 \mathrm{mg} / 100 \mathrm{~g}$ 으로 약 3.9 배 정도나 높아지는 것으로 나타났으며, 굽기에서 $5,128.7 \mathrm{mg} / 100 \mathrm{~g}$, 볶기에서도 $4151.1 \mathrm{mg} / 100 \mathrm{~g}$ 으로 생시료보다 현저하게 증가하는 경향 을 보였다. $\alpha$-Tocopherol 성분은 튀기기에서 유의적으로 높게 나타났고, 볶기, 굽기, 찌기, 삶기 순으로 나타났으며 $\beta$-tocopherol도 유사한 경향으로 나타났다. 특히 $\gamma$ tocopherol과 $\delta$-tocopherol은 튀기기에서 유의적으로 증가 하는 경향을 나타내었고, 볶기에서도 유의적으로 증가하 였다. 이는 기름 성분에서 유래한 $\alpha$-tocopherol 영향 때문으 로 당근은 기름에 볶는 요리가 항산화 성분인 비타민 $\mathrm{E}$ 의 좋은 급원으로 여겨진다. 이는 생시료와 찌기, 굽기, 찌기 등에서 유의차가 없었다. 이는 유지를 이용한 당근의 튀김 이나 볶기는 지용성 비타민의 손실도 적음을 알 수 있었다. 엽산은 당근의 조리법에 따른 차이가 없었다.

\section{감사의 글}

본 연구는 2016년도 식품의약품안전처의 연구개발비 (15162MFDS039)로 수행되었으며 이에 감사드립니다.

\section{Conflict of interests}

The authors declare no potential conflict of interest. 


\section{ORCID}

Kunjong Lee https://orcid.org/0000-0002-6046-2229

Heajung Chung https://orcid.org/0000-0002-0244-1825

\section{References}

Ahn MS. A study on the changes in physico-chemical properties of vegetables by Korean traditional cooking methods. J Korean Soc Food Cult, 14, 177-188 (1999)

AOAC. Official Methods of Analysis. 15th ed, Association of Official Analytical Chemists, Washington DC, USA, p 210-219 (1996)

Cha YJ, Jung YS, Kim JW, Youn KS. Quality characteristics and antioxidative activity of mung bean starch gels added with carrot, spinach and mulberry juice. J East Asian Soc Dietary Life, 21, 46-52 (2011)

Chae YC. Quality characteristics of pork cutlet by cooking method. Korean J Food Cookery Sci, 21, 490-495 (2005)

Cho SH, Shin SK, Park HG, Song MR, Cha YH, Han MR, Yoo KM. Food Chemistry, 3rd ed, Gyomoon Publishers, Seoul, Korea, p 155-156 (2014)

Cho YS, Park SK, Chun SS, Moon JS, Ha BS. Proximate, sugar and amino acid composition of Dolsan leaf mustard (Brassica juncea). J Korean Soc Food Nutr, 22, 48-52 (1993)

Choi SN, Kim HJ, Chung NY. Nutrient intakes, nutritional knowledge, food habits, and lifestyle behaviors of obese children. J Korean Diet Assoc, 17, 349-363 (2011)

Chun JY, Martin JA, Chen L, Lee J, Ye L, Eitenmiler RR. A differential assay of folic acid and total folate in foods containing enriched cereal-grain products to calculate $\mu \mathrm{g}$ dietary folate equivalents ( $\mu \mathrm{g}$ DFE). J Food Compos Anal, 19, 182-187 (2006)

DeVries JW, Rader JI, Keagy PM, Hudson CA, Angyal G, Arcot J, Castelli M, Doreanu N, Hudson C, Lawrence P, Martin J, Peace R, Strandler HS, Szpylka J, van den Berg H, Wo C, Wutz C. Microbiological assay-trienzyme procedure for total folates in cereals and cereal foods: Collaborative study. J AOAC Int, 88, 5-15 (2005)

Granado F, Olemdilla B, Blanco I, Rojas-Hidalgo E. Carotenoid composition in raw and cooked Spanish vegetables. J Agric Food Chem, 40, 2135-2140 (1992)

Han JA, Jin HK, Bi HX. Effect of carrot powder on anti-oxidative and quality characteristics of perilla-Dasik. J Korean Soc Food Sci Nutr, 44, 1832-1838 (2015)
Hong JY, Choi YJ, Kim MH, Shin SR. Study on the quality of apple dressing sauce added with pine mushroom Trichodoma matsutake Sing and chitosan. Korean J Food Preser, 16, 60-67 (2009)

https://www.bing.com/search?q=www.healthline.com $\% 2$ Fhe alth $\% 2$ Fbeta-carotene-benefit $+\& q s=n \&$ form $=$ QBRE\&sp $=-1 \& \mathrm{pq}=$ www.healthline.com $\% 2$ Fhealth $\% 2$ Fbeta-carote ne-benefit $+\& s c=0-48 \&$ sk $=\&$ cvid $=410$ A3A4DF06E4047 A427D63BB6FC7E83 (assessed Jun 2020)

Hwang KH, Shin JA, Lee KT. True retention and $\beta$-carotene contents in 22 blanched vegetables. J Korean Soc Food Sci Nutr, 45, 990-995 (2016)

Jang HL, Park SY, Lee JH, Hwang MJ, Choi YM, Kim HR, Hwang JB, Seo DW, Kim SH, Nam JS. Changes in nutritional composition and physicochemical properties of mustard leaf (Brassica juncea) kimchi during fermentation. Korean J Food Nutr, 29, 706-715 (2016)

Jeon KH, Kwon KH, Kim EM, Kim YB, Sohn DI, Choi JY. Effect of cooking methods with various heating apparatus on the quality characteristics of chicken. Korean J Culinary Research, 20, 201-213 (2014)

Kang S, Lee SH, Shim YN, Oh MJ, Lee NR, Park S. Antioxidant capacity of anthocyanin-rich fruits and vegetables and changes of quality characteristics of black carrot added pudding according to storage. J Appl Biol Chem, 59, 273-280 (2016)

Kim BC, Hwang JY, Wu HJ, Lee SM, Cho HY, Yoo YM, Shin HH, Cho EK. Quality changes of vegetables by different cooking methods. Korean J Culinary Research, 18, 40-53 (2012)

Kim CJ, Chae YC, Lee ES. Changes of physico-chemical properties of beef tenderloin steak by cooking methods. Korean J Food Sci Ani Resour, 21, 314-322 (2001)

Kim H, Hwang JB, Kim SN, Choi Y, Kim SM, Han HK, Yang MR, Kim HR. Changes of nutrient composition and retention rate of sweet pepper by different types and blanching method. Korean J Food Cook Sci, 32, 433-440 (2016)

Kim HA, Lee KH. Quality characteristics of Jungkwa made with carrot, using different manufacturing methods. J East Asian Soc Dietary Life, 24, 242-251 (2014a)

Kim HG, Chung HJ. Comparison of nutrient content and retention rate among chuichung cucumber, white dadagi cucumber, and yellowish overripe cucumber according to different cooking methods. J Korean Soc Food Sci Nutr, 46, 1350-1357 (2017a) 
Kim HJ, Lee KJ, Kim SM, Chung HJ. Nutrient retention factor of $1^{+}$quality grade Hanwoo beef using different cooking methods. Korean J Food Sci Ani Resour, 30, 1024-1030 (2010)

Kim HY, Kim HG, Chun JY, Chung HJ. Changes in $\beta$ carotene, vitamin $\mathrm{E}$, and folate compositions and retention rates of pepper and paprika by color and cooking method. J Korean Soc Food Sci Nutr, 46, 713-720 (2017b)

Kim HY, Lim YI, Rucell RM. Changes in carotenoids contents in pureed and cooked carrot and spinach during storage. Korean J Soc Food Cookery Sci, 19, 83-95 (2003)

Kim MK, Kim MH, Yu MS, Song YB, Seo WJ, Song KB. Dehydration of carrot slice using polyethylene glycol and maltodextrin and comparison with other drying methods. J Korean Soc Food Sci Nutr, 38, 111-115 (2009)

Kim YT, Lee M, Kim AJ. Changes in antioxidative activities and general composition of mung beans according to roasting temperature. J East Asian Soc Diet Life, 24, 217-223 (2014b)

Korean Food Industry Association (KFIA). Korean Food Standards Codex II-General Test Method. Moonyoung, Seoul, Korea, p 55-63 (2012)

Krinsky NI. Antioxidant functions of carotenoids. Free Radical Biol Med, 7, 617-635 (1989)

Krinsky NI. Membrane antioxidants. Ann N Y Acad Sci, 551, 17-32 (1988)

Lee HJ, Kim JG. The changes of components and texture out of carrot and radish pickles during the storage. Korean J Food Nutr, 13, 563-569 (2000)

Lee J, Landen WO Jr, Phillips RD, Eitenmiier RR. Application of direct solvent extraction to the LC quantification of vitamin $\mathrm{E}$ in peanuts, peanut butter, and selected nuts. Peanut Sci, 25, 123-128 (1998)

Lim JY, Kim SC, Kim SN, Choi YM, Yang MR, Cho IH, Kim HR. Protein and amino acid contents in Backtae, Seoritae, Huktae, and Seomoktae soybeans with different cooking methods. Korean J Food Cook Sci, 32, 567-574 (2016)

Lee KJ, Kim HG, Kwon YS, Chung HJ. Retention factors influencing Hanwoo stock (broth) and boiled beef. Korean J Community Living Sci, 25, 261-269 (2014)

Murphy EW, Criner PE, Gray BC. Comparisons of methods for calculating retentions of nutrients in cooked foods. J Agric Food Chem, 23, 1153-1157 (1975)

National Institute of Agricultural Sciences. Food Composition Table 7th revision. Rural Development Administration,
Suwon, Korea, p 200 (2006)

National Rural Resources Development Institute (NRRDI), Food Composition Table. 7th ed, National Rural Resources Development Institute, R.D.A, Suwon, Korea, P 158 (2019)

Ogunlesi AT, Lee CY. Effect of thermal processing on the stereoisomerization of major carotenoids and vitamin A value of carrots and green vegetables. Food Chem, 4, 311-318 (1979)

Oh MS. Changes in mineral content in several root vegetables by various cooking methods. Korean J Soc Food, 12, 40-45 (1996)

Oh YS, Hwang JH, Oh HJ, Lim SB. Physicochemical properties and antioxidative activities of mixed citrus and carrot juice. J Korean Soc Food Sci Nutr, 41, 598-604 (2012)

Park SJ, Park SH, Chung HJ, Lee JS, Hyun TS, Chun JY. Effects of different cooking methods on folate retention in selected mushrooms. Korean J Food Preserv, 24, 1103-1112 (2017)

Paek HY, Kim JH, Kwak EJ. Quality characteristics Doenjang added with vegetable powder. J East Asian Soc Dietary Life, 29, 326-335 (2019)

Sanz-Serrano J, Cerain AL, Garayoa R, Azqueta A, Vettorazzi A. Genotoxicity evaluation of fried meat: A comprehensive review. Food Chem Toxicol, 136, 110943 (2020)

Song BH, Hwang SH, Lee JD, Kim HJ, Chung HL, Moon HK. A study on the mineral contents of Korean common foods and analytical methods. 2. Potassium. Korean J Food Hygiene, 7, 37-44 (1992)

Stea TH, Johansson M, Jagerstad M, Frolich W. Retention of folate in cooked, stored and reheated peas, broccoli and potatoes for use in modern large-scale service systems. Food Chem, 101, 1095-1107 (2007)

Suh HJ, Chung SH, Choi YM, Bae SH, Kim YS. Changes in sugar content of sweet potato by different cooking methods. Korean J Soc Food Sci, 14, 182-187 (1998)

Thomas JB, Kline MC, Gill LM, Yen JH, Duewer DL, Sniegoski LT, Sharpless KE. Preparation and value assignment of standard reference material $968 \mathrm{c}$ fatsoluble vitamins, carotenoids, and cholesterol in human serum. Clin Chim Acta, 305, 141-155 (2001)

United States Department of Agriculture (USDA). USDA table of nutrient retention factors release 6 . https://www.bing.com /search?q=\%28http $\% 3 \mathrm{~A} \% 2 \mathrm{~F} \% 2 \mathrm{Fwww} .+$ ars.usda.gov\%2 FSP2UserFiles\%2FPlace\%2F80400525\%2FData\%2Fret 
$\mathrm{n} \% 2$ Fretn06.pdf\%2C\&form=EDGSPH\&mkt=ko-kr\&htt psmsn $=1 \&$ msnews $=1 \&$ plvar $=0 \&$ refig $=$ ec58bac5f $2 \mathrm{f} 8443$ 2b0e5b5940a6b3ae9\&PC =SMTS\&sp=-1\&pq=028htt p $\% 3 \mathrm{~A} \% 2 \mathrm{~F} \% 2 \mathrm{Fwww}$.+ars.usda.gov\%2Fsp2userfiles $\% 2 \mathrm{~F}$ place $\% 2 F 80400525 \% 2$ Fdata $\% 2$ Fretn $\% 2$ Fretn06.pdf $\% 2 C$ $\& s c=0-75 \& q s=n \& s k=\& c v i d=e c 58 b a c 5 f 2 f 84432 b 0 e 5 b 59$ 40a6b3ae9 (accessed Jul 2017)

Xu ZZ, Huang GQ, Xu TC, Liu LN, Xiao JX. Comparative study on the Maillard reaction of chitosan oligosaccharide and glucose with soybean protein isolate. Int $\mathrm{J}$ Biol Macromol, 131, 601-607 (2019)

Yang JB, Ko MS, Kim KS. Physico-chemical changes in pork bellies with different cooking methods. Korean J Food Preserv, 16, 87-93 (2009)

Ziaiifar AM, Achir N, Courtois F, Trezzani I, Trystram G. Review of mechanisms, conditions, and factors involved in the oil uptake phenomenon during the deep-fat frying process. Int J Food Sci Technol, 43, 1410-1423 (2008) 